\title{
Uma ferramenta interativa para análise de padrões baseada em entropia
}

\author{
Luiz Gustavo Martins
}

DisSERTAÇÃo APRESENTADA

$\mathrm{AO}$

Instituto de Matemática e Estatística

DA

Universidade DE SÃo Paulo

PARA

PARA obtenção do título de Mestre

EM

Ciência da Computação

Área de Concentração: Ciência da Computação

Orientador: Prof. Dr. Marco Dimas Gubitoso

- São Paulo, outubro de 2005 - 


\section{Uma ferramenta interativa para análise de padrões baseada em entropia}

Este exemplar corresponde à redação final da dissertação devidamente corrigida e defendida por Luiz Gustavo Martins e aprovada pela comissão julgadora.

São Paulo, 13 de outubro de 2005

Banca examinadora:

- Prof. Dr. Marco Dimas Gubitoso - IME-USP

- Prof. Dr. Roberto Marcondes Cesar Junior - IME-USP

- Prof. Dr. Arthur Gruber - FMVZ-USP 
Aos meus pais. 


\section{Agradecimentos}

Gostaria de agradecer aos meus pais por amor que me deram e a toda minha família que sempre me apoiou. Mãe, obrigado pela paciência e por entender minha ausência devido aos estudos. Pai, obrigado por me ajudar nos momentos difíceis e me ensinar a superá-los.

Ao meu orientador Professor Marco Dimas Gubitoso por me ajudar nessa etapa. Seu apoio, competência, sabedoria paciência e boa vontade foram fundamentais para concretização do meu trabalho.

À minha namorada Andrea Principe que me apoiou e sempre me incentivou. Obrigado por entender meu pouco tempo disponível devido aos estudos.

Aos meus amigos do IME que sempre me ajudaram de alguma forma em toda esta jornada, desde a concluir as diciplinas até a conclusão da dissertação. Em especial a Ricardo Bueno, Roberto Speicys, Julian, Fabio Ide, Elidia, Paulo Machado, Ricardo Moe, Marcus Meio, Jay Santos, Rafael Bota, André Burzum, Mauricio Moura, Tiago Marcus, Roberto Guto, Ricardo Skubs, Mazzon, Gisela Tunes e todos os demais que sabem que me ajudaram, todos foram e sempre serão muito importantes.

Aos meus amigos do MAPS e PR\&A, que me ajudaram muito a consiliar trabalho e mestrado e ter a determinação para concluir esta fase. Marcos Yamamato, Marcelo Eiji, João Paulo, Daniel Sakai, Fernando Correa Lima, Claudio Queiroz, Thiago André, Sérgio Malacrida, Cesar Galante, Victor Pafume muito obrigado a todos vocês. Um agradecimento especial a Edson Bignoto, sem sua ajuda não seria possível terminar a parte de testes.

Enfim, a Deus, que me deu saúde e luz para chegar onde estou hoje. 


\section{Resumo}

Com o aumento da capacidade computacional, está ficando cada vez mais fácil e barato armazenar grandes quantidades de dados. Esses dados representam enormes quantidades de informação que podem conter relações ou padrões de comportamento escondidos que poderiam ajudar um analista a desenvolver desde novas soluções de marketing até novos tipos de tratamento médico ou até mesmo novos remédios.

O problema de uma quantidade de dados tão grande é que ela só pode ser analisada, em tempo viável, com o auxílio de computadores. Para tanto são necessários algoritmos e tratamentos especiais para esses dados, possibilitando assim que um analista consiga chegar a conclusões úteis. Este trabalho emprega o conceito de entropia e quantidade de informação a um software para procura por relações entre variáveis em conjuntos de dados. O software criado, Entrop Calc, possibilita a um usuário, com bom conhecimento específico dos dados a ser analisados, chegar rapidamente a hipóteses razoáveis e padrões escondidos nesses dados. Além de fazer os cáculos propostos, é de fácil utilização e permite a visualização simples e direta dos dados utilizados bem como dos resultados obtidos.

Testes feitos com usuários leigos em computação demonstaram que o $\boldsymbol{E}$ trop Calc consegue atingir estes objetivos. 


\begin{abstract}
As the computational capacity increases, it becomes easier and cheaper to keep larger amounts of data. These data represent a huge amount of information which may contain hidden relationships or patterns which could help an analyst to develop, from new marketing solutions to new kinds of medical treatment or even new medicines.

The problem with such a large amount of data is that it can only be analyzed, in viable time, with computer help. In order to accomplish this, algorithms and special treatment for this data are needed, enabling an analyst to reach useful conclusions. This work employs the concept of entropy and quantity of information in a software to search relationships between variables from data sets. The software, Entrop Calc, enables an user to quickly reach sensible suppositions and hidden patterns in these data. Besides performing the proposed computations, it is easy to use and allows a simple and straightforward visualization of the data as well as the obtained results.

Tests done with lay users (in computer science) proved that Entrop Calc is able to accomplish these goals.
\end{abstract}




\section{Sumário}

Lista de Figuras

Nomenclatura

1 Introdução

1.1 A Importância de Encontrar Padrões

1.2 O Problema

1.3 Objetivos

1.4 Contribuição .

1.5 Organização .

2 Introdução Teórica

2.1 Dado e Informação

2.1.1 Quantidade de Informação

2.2 Entropia

2.2.1 História

2.2.2 Definição

2.2.3 Entropia Condicional

p. 9

2.2.4 Propriedades da Entropia de Shannon . . . . . . . . . . .

p. 11

2.2.5 Transmissão de Informação

p. 12

2.3 Discretização . . . . . . . . . . . . . . . . . . . . . . . p. 13

2.3.1 Discretização por Intervalos de Mesmo Tamanho .

p. 14 
2.3.2 Discretização por Intervalos de Mesma Freqüência . . . . . . . . p. 15

2.3.3 Discretização Baseada em Entropia . . . . . . . . . . . . . . p. 15

2.4 Mineração de Dados — Data-mining . . . . . . . . . . p. 17

2.4 .1 Objetivos de Mineração de Dados . . . . . . . . . . . . p. 18

2.4.2 Tipos de Conhecimento Descobertos com Mineração de Dados p.19

2.4.3 Perigos ao se usar Mineração de Dados . . . . . . . . . . . . . p. 19

3 Trabalhos Relacionados p. 21

3.1 Software Específicos de Cálculo Científico . . . . . . . . . . . p. 21

3.2 Software Específicos de Cálculo Estatístico . . . . . . . . . . . p. 23

3.3 Calculadoras Simples para Projetos Específicos . . . . . . . . . . p. 25

3.4 Software Específico de Aprendizado Computacional e Mineração de Dados p. 25

4 O Software $\quad$ p. 27

4.1 História do Desenvolvimento . . . . . . . . . . . . . p. 28

4.2 Implementação Matemática . . . . . . . . . . . . . . . . . p. 29

4.3 Implementação Gráfica . . . . . . . . . . . . . . . . . . . . p. 31

4.3 .1 Menus . . . . . . . . . . . . . . . . . . . . 32

4.3.2 Tela de Opções de Cálculo de Entropia . . . . . . . . . . . . p. 33

4.3.3 Tela de Opções de Discretização . . . . . . . . . . . . . . . p. 34

4.3 .4 Tela Histogramas . . . . . . . . . . . . . . . . . p. . 35

4.3 .5 Tela Principal . . . . . . . . . . . . . . . p. 36

4.4 Arquivo de Entrada . . . . . . . . . . . . . . . . p. 37

4.5 Arquivo de Resultados de Saída . . . . . . . . . . . . . . . p. 38

4.6 Executando o Software . . . . . . . . . . . . . . . p. . 39

5 Tutorial p. 41 
6.1 Primeira Série de Experimentos . . . . . . . . . . . . . p. 44

6.1 Resultados . . . . . . . . . . . . . . . p. 44

6.1.2 Resultados com Combinação de Mais Variáveis . . . . . . . . . . p. p. 45

6.1.3 Resultados com Coluna Aleatória Adicional . . . . . . . . . p. 46

6.1.4 Conclusão da Primeira Etapa . . . . . . . . . . . . . p. 47

6.2 Segunda Série de Experimentos . . . . . . . . . . . . . p. 48

6.2.1 Resultados Simples(1 Variável por Combinação) . . . . . . . . . p. 48

6.2.2 Resultados com Duas Variáveis . . . . . . . . . . . p. 51

6.2.3 Resultados com Três Variáveis . . . . . . . . . . . . p. 53

6.3 Análise das Impressões do Usuário . . . . . . . . . . . . . . . . . p. 54

6.3.1 Resultado das Impressões do Usuário A . . . . . . . . . . . . . p. 55

6.3.2 Resultado das Impressões do Usuário B . . . . . . . . . . p. 56

7 Conclusão $\quad$ p. 58

7.1 Trabalhos Futuros . . . . . . . . . . . . . p. 60

Apêndice A - Apêndice $\quad$ p. 61

A.1 Biografia de Claude Shannon . . . . . . . . . . . p. 61

$\begin{array}{ll}\text { Referências } & \text { p. } 64\end{array}$ 


\section{Lista de Figuras}

1 Tela do produto final . . . . . . . . . . . . p. 27

2 Tela de opções do cálculo de entropia . . . . . . . . . . . . . . p. 34

3 Tela de escolha das opções de Discretização . . . . . . . . . . . . . . . p. 35

4 Tela de Histograma $1 \ldots \ldots \ldots \ldots$ p. 36

5 Árvore de Entropia . . . . . . . . . . . . . . . . p. 37

6 Configuração inicial do Tutorial . . . . . . . . . . . . . . p. 42

7 Configuração de cálculo com 2 variáveis . . . . . . . . . . . . . p. 43

8 Histograma da variável CHAP3 Equity . . . . . . . . . . . p. 51 


\section{Nomenclatura}

E $\quad$ Operador média, página 7

$H(X)$ Função Entropia sobre a variável aleatória $\mathrm{X}$, página 9

$H(X, Y)$ Função Entropia Conjunta de $(\mathrm{X}, \mathrm{Y})$, página 10

$H(Y \mid X)$ Função Entropia Condicional de $Y$ dado $X(Y \mid X)$, página 10

I Quantidade de informação, página 7

$L(\theta \mid x)$ Função verossimilhança, página 7

$P(\theta) \quad$ Incerteza sobre $\theta$, página 6

$P_{x} \quad$ Probabilidade a posteriori da ocorrência de $x$, página 7

U Função de incerteza teste, página 7

$X \quad$ Variável aleatória que represanta as possíveis saídas de um experimento, página 7

$x \quad$ Uma realização da variável $X$, página 7

$\theta \quad$ Estado da natureza, página 6 


\section{Introdução}

A cada dia, mais e mais dados sobre os mais diversos assuntos são armazenados. Desde as empresas de cartões de crédito, bancos, lojas, supermercados, hospitais, universidades, pontos de venda eletrônicos, reservas de passagens, etc. Em um futuro não muito distante, tudo poderá ser arquivado de alguma forma por computadores, gerando assim quantidades gigantescas de dados.

Segundo Shapiro (8)

"Foi estimado que a quantidade de dados no mundo dobre a cada 20 meses.

O tamanho e o número de bancos de dados provavelmente aumenta-rá ainda mais rápido"

Quantidades muito grandes de dados não podem ser analisadas por pessoas de forma eficiente e em um tempo razoável, sem uma ferramenta adequada. O computador vem auxiliar nessa tarefa. Se bem direcionado, quantidades enormes de dados podem ser verificados e as relações escondidas podem ser encontradas, facilitando assim o trabalho do pesquisador que só vai precisar analisar os resultados, o que consome bem menos tempo e recursos e utiliza melhor o conhecimento do pesquisador.

\subsection{A Importância de Encontrar Padrões}

Ao lidar-se com grandes volumes de dados, é necessário ter um modo para se encontrar estruturas nesses dados, um padrão de comportamento, de tal forma que eles possam ser encarados de maneira estruturada e não completamente aleatória.

As estruturas ou padrões que estão sendo procuradas são restrições, relações e dependências entre os dados que não são imediatamente identificáveis, dada à vasta quantidade de dados. A razão mais importante para se achar estruturas é a possibilidade de 
se fazer previsões a respeito deles: por exemplo, se alguns dos dados são conhecidos em alguns campos, então qual seria a distribuição de probabilidade para outros campos. Um empresário pode querer prever o comportamento de compra de seus clientes a partir das compras que fizeram anteriormente.

São necessários algoritmos rápidos para lidar com os dados de uma forma útil. A complexidade dos métodos tende a aumentar exponencialmente com o número de dimensões (variáveis) tal como o conjunto de dados necessários para se caracterizar de forma significante uma propriedade. Esta é a motivação principal dos métodos de "seleção de variáveis", "seleção de campos" e "redução de variáveis".

Com isso, pode-se tentar achar algum padrão desconhecido a partir de grandes conjuntos de dados que a princípio pareciam sem sentido. Esse é um campo onde a computação ajuda muito, já que para uma pessoa ficar analisando grandes quantidades de dados seria inviável, enquanto que o computador pode ficar dia e noite processando os dados a procura de relações escondidas de forma incansável.

Nesse sentido, se está adotando um caminho muito diferente da maioria das ciências, onde primeiro se formula uma hipótese pare depois testá-la. No reconhecimento de padrões se está voltado a derivar hipótese dos dados em primeiro lugar ao invés de tentar deduzí-la ou derivá-la de alguma regra.

\subsection{O Problema}

Pesquisadores acabam por acumular grandes quantidades de dados e precisam de ferramentas para achar correlações e dependências nesse grande amontoado de dados de uma forma inteligente, razoavelmente rápida, facilitando assim o trabalho do pesquisador, que pode então encaminhar sua pesquisa de forma mais produtiva.

A solução adotada para esse trabalho foi baseada em cálculo de Entropia, Entropia Condicional e Quantidade de Informação associada aos dados.

Para tanto é necessário observar que esses dados nem sempre são de natureza discreta, fugindo assim do campo de atuação da Entropia que foi implementada. A solução foi disponibilizar algoritmos de discretização para poder haver um tratamento das séries antes de sua análise, podendo assim melhorar os resultados que podem ser obtidos.

O software produzido tem como foco pessoas que entendam bem sobre os dados 
utilizados, para, a partir de seu conhecimento e os resultados apresentados pelo software, chegar a conclusões válidas sobre os dados, evitando interpretações errôneas que são muito comuns nesse tipo de análise.

\subsection{Objetivos}

Esse projeto visa estudar conjuntos de dados e, utilizando o conceito de entropia de Shannon, procurar por estruturas e padrões nesses dados de tal forma que um pesquisador com maior conhecimento dos dados de entrada possa tirar conclusões sobre os resultados alcançados.

Para tanto, busca-se uma ferramenta que calcule a entropia e mostre os resultados de forma simples e fácil de ser analisada e que permita a usuários sem conhecimento específico de computação o acesso a este tipo de análise.

\subsection{Contribuição}

A ferramenta citada em 1.3 foi desenvolvida e chamada de Entrop Calc. Além do cálculo de entropia ainda tem, como funcionalidade auxiliar, a discretização de séries por três métodos diferentes (EWD, EFD, Discretização baseada em Entropia) e um visualizador de histogramas para uma análise visual melhor dos dados.

\subsection{Organização}

O texto está sub-dividido em capítulos. No capítulo 2 foi mostrada toda a teoria e as definições utilizadas nesse trabalho, deixando bem formalizado e separado alguns conceitos que são normalmente confundidos. O capítulo 3 descreve alguns trabalhos relacionados, e qual a diferença desses trabalhos para o produzido. O capítulo 4 descreve o software que foi produzido, desde a tecnologia usada e o porquê de sua escolha até como foi utilizada, explicando as funcionalidades e a sua utilização. O capítulo 6 tem os resultados dos experimentos que foram feitos e o capítulo 7 apresenta as conclusões alcançadas com esse trabalho. 


\section{Introdução Teórica}

Para a melhor compreensão do desenvolvimento desse projeto, será necessária a definição de alguns conceitos, bem como a apresentação de alguns pontos teóricos como Dado, Informação, Entropia, Quantidade de Informação, Discretização e Mineração de Dados.

\subsection{Dado e Informação}

O que pode se entender como Dado? e o que vem a ser Processamento de Dados? Dado o mesmo que Informação?

Na literatura existem várias definições para Dado e Informação e freqüentemente não congruentes.

No dicionário Houaiss da Língua Portuguesa temos como definição para Dado na área de informática:

1 - Substantivo Masculino

Rubrica: informática.

Informação capaz de ser processada por um computador.

De acordo com o livro Fundamentals of Database Systems, Dados são entendidos como fatos conhecidos que podem ser gravados e que tenham um significado implícito.

Para o Professor Valdemar Setzer em seu artigo "Dado, Informação, Conhecimento e Competência", Dado é descrito como sendo uma seqüência de símbolos quantificados ou quantificáveis. Como exemplos para dado nessa definição temos fotos, figuras, sons gravados e animações.

A partir desse raciocínio dado é necessariamente uma entidade matemática, logo 
puramente sintática. Dados podem ser totalmente descritos através de representações formais. Sendo assim, podem ser quantificáveis, podem então ser armazenados em um computador e processados por ele.

Para esse texto usaremos a definição dada pelo Professor Setzer. Dados são elementos puramente sintáticos e por si só não tem significado nenhum. Um computador pode manipular esses dados de diversas formas mesmo não compreendendo qual o significado deles. Mesmo sem a compreensão desse significados um computador pode manipular esses dados, já que essas manipulações são puramente sintáticas sendo de certa forma funções matemáticas aplicadas a entidades matemáticas. Como exemplos dessa manipulação em textos são a formatação, a ordenação, a comparação com outros textos, estatísticas de palavras empregadas mesmo sem saber do que se trata o texto e até mesmo não importando a língua em que ele está escrito, com tanto que existam as regras específicas para essa outra língua implementadas no software de tratamento de texto.

A definição mais básica para a Informação é: uma mensagem recebida e entendida.

Do Dicionário Houaiss temos as seguintes definições para Informação:

1 - quantidade numérica que mede a incerteza do resultado de um experimento a realizarse; medida quantitativa do conteúdo da informação

2 - mensagem suscetível de ser tratada pelos meios informáticos; conteúdo dessa mensagem; interpretação ou significado dos dados; produto do processamento de dados.

A definição de Informação dada por D. Basu (4) que é :"Informação é o que ela faz por você, muda sua opinião". Mesmo esse conceito sendo um pouco subjetivo ainda assim define bem o que se entende por Informação.

No texto de Waldemar Setzer temos também uma definição para Informação que é: "Informação é uma abstração informal, que esta na mente de alguém, representando algo significativo para essa pessoa."(9). Como exemplo podemos usar a frase: "O Brasil é a terra do futebol" é um exemplo de frase que contém informação no sentido descrito pelo professor Setzer - desde que seja lida ou ouvida por alguém e que Brasil signifique para essa pessoa um país e futebol um esporte.

Se a representação da informação for feita por meio de dados, como na frase sobre o Brasil, ela poderá ser armazenada em computador. O que é armazenado na máquina não é informação, mas sua representação em forma de dados. Essa representação pode 
ser transformada pela máquina, como na formatação de um texto, e então seria uma transformação sintática. A máquina não pode mudar o significado a partir deste, já que ele depende de uma pessoa que possui a informação. Obviamente a máquina pode embaralhar os dados de modo que eles passem a ser ininteligíveis pela pessoa que os recebe, deixando de ser informação para essa pessoa. Além disso, é possível transformar a representação de uma informação de modo que mude de informação para quem a recebe, por exemplo, o computador pode mudar o nome do país de Brasil para Argentina. Houve mudança no significado para o receptor, mas no computador a alteração foi puramente sintática, uma manipulação matemática de dados.

Para o texto teremos uma distinção fundamental entre Dado e Informação, o primeiro irá se referir a algo puramente sintático e o segundo contém necessariamente semântica.

Um computador pode armazenar uma estrutura de dados de tal forma que ela contenha uma semântica, mas isso não quer dizer que a máquina pode entender essa semântica. Atualmente uma máquina não consegue entender semânticas.

Para poder trabalhar com o conceito de Informação e tentar quantifica-lo de alguma forma, iremos dividi-lo em dois tipos: Informação Cultural e Informação experimental.

A Informação Cultural é a que está em nosso cérebro e por ser muito subjetiva, não se pode definir um ganho de informação por meios matemáticos.

A Informação Experimental está relacionada a resultados de experimentos que podem ser observados. Nesse caso, como veremos mais adiante no texto, podemos descobrir qual experimento tem maior ganho de Informação Experimental. Esse processo pode ser comparado a um adestramento de modelos.

\subsubsection{Quantidade de Informação}

Para analisar a Informação e poder quantifica-la, teremos que definir um parâmetro de estudo que será entendido como o estado da natureza $\theta$. A partir de experimentos iremos refinando esse parâmetro e esse refinamento é o que pode ser entendido como Ganho de Informação e isso será medido.

Vamos considerar uma distribuição de probabilidade $P(\theta)$ sobre $\theta$ que irá significar a incerteza sobre $\theta$.

Quanto mais experimentos sobre o parâmetro $\theta$ forem realizados mais refinado ficará 
a distribuição $P(\theta)$. Esse processo pode ser comparado com um processo de "adestramento".

Dado um experimento $X$ cujo resultado obtido foi $x$. Dessa forma passamos de $P(\theta)$ para $P(\theta \mid x)$. Para calibrar a informação, usa-se o operador de Bayes:

$$
P(\theta \mid x) \propto L(\theta \mid x) \times P(\theta)
$$

Onde $L(\theta \mid x)$ é a função Verossimilhança (em inglês (Likelihood)).

Para descobrir a quantidade de informação sobre $\theta$ é preciso definir a função de incerteza $U$ (Uncertainty) que é uma função definida na família de todas as funções de densidade de probabilidade. $U$ é considerada como um índice que mede a incerteza da função de probabilidade $P$, para $\theta$.

Dado um experimento $X$ relacionado ao parâmetro de interesse $\theta$. Seja $P$ a função de probabilidade a priori e $P_{x}$ a função de probabilidade a posteriori. $U$ é a função de incerteza e $E$ é o operador média, temos então:

$$
U(P) \geq E\left\{U\left(P_{x}\right)\right\}
$$

Que quer dizer que se espera que a incerteza a posteriori seja menor que a incerteza a priori.

Com essa definições pode-se chegar ao operador de quantidade de informação $I$ sobre $\theta$, contido em $x$ quando a priori é $P$ e a incerteza é $U(10)$ :

$$
I\{x, P, U\}=U(P)-E\left\{U\left(P_{x}\right)\right\} \geq 0 \Longleftrightarrow U \text { for côncava } .
$$

Logo quanto maior $I$, maior a quantidade de informação adicionada a $\theta$.

Para a escolha da função de incerteza, é necessário apenas que esta seja côncava, como a Variância ou a Entropia. 


\subsection{Entropia}

\subsubsection{História}

Professor Claude Shannon, parente distante de Thomas Edison, trabalhou no Bell Labs de 1941 a 1972 e foi nesse período que escreveu "A Mathematical Theory of Communication" (11) que é considerado marco na história em muitos sentidos. Nesse documento Shannon formulou um modelo de comunicação que se distinguia de todos outros propostos até então por seu embasamento matemático.

Shannon observou que o processo de comunicação é puramente estocástico, o significado semântico dos dados (informação) não tem importância nenhuma na teoria. Em seu paradigma, os dados de uma fonte devem ser transmitidos através de um canal de comunicação. Nesse sistema ainda é previsto um codificador para a mensagem entre a fonte e o canal e um decodificador ao final do canal. A teoria proposta tentar responder o quâo rápido e confiável os dados podem ser transmitidos através do canal de comunicação quando os codificadores e decodificadores estão sujeitos a otimizações.

Tentando resolver esse problema de comunicação proposto Shannon introduziu alguns conceitos matemáticos. O principal dentre esses conceitos é a noção de entropia de uma variável aleatória e por extensão de uma sequência aleatória. Criou também o conceito de entropia condicional entre duas variáveis ou sequências aleatórias.

A entropia passou a ser medida geral de incerteza em variáveis aleatórias e é esse conceito que será bem explorado em nosso trabalho. Para diferenciar um pouco dos outros conceitos de entropia como o de termodinâmica, sempre que for mencionado entropia nesse trebalho, será referente à entropia de Shannon(11)(12).

Uma biografia mais completa de Claude Shannon está presente no apêndice A.1.

\subsubsection{Definição}

Seja $X$ uma variável aleatória discreta que pode assumir um número finito de valores $x_{1}, x_{2}, \ldots, x_{n}$ com probabilidades $p_{1}, p_{2}, \ldots, p_{n}$ de tal forma que $p_{i} \geq 0, i=1,2, \ldots, n$ e $\sum_{i=1}^{n} p_{i}=1 P$. Tentaremos obter um valor que represente a quantidade de incerteza associadla ao evento $\left\{X=x_{i}\right\}, i=1,2, \ldots, n$. Dada a função $h$ definida no intervalo $(0,1]$ e $h(p)$ como sendo então a função de incerteza do evento $\mathrm{X}=x$. Para cada $n$ define-se 
a função $H_{n}$ das $n$ variáveis $p_{1}, p_{2}, \ldots, p_{n} . H_{n}\left(p_{1}, p_{2}, \ldots, p_{n}\right)$ é então interpretada como a média das incertezas associadas ao evento $\left\{X=x_{i}\right\}, i=1,2, \ldots, n$ dado por:

$$
H_{n}\left(p_{1}, p_{2}, \ldots, p_{n}\right)=\sum_{i=1}^{n} p_{i} h\left(p_{i}\right)
$$

A função que segue as definições de $h$ é $\log _{b} p_{i}$, onde $b>1$ e $\log _{b} 0=0$. Com isso temos a conhecida função de Entropia de Shannon:

$$
H(X)=H(f(x) \mid x \in \operatorname{dom}(X)):=-\sum\left(f(x) * \log _{2} f(x)\right) \text { bits }
$$

Para mais detalhes sobre a demonstração até o resultado final temos as referências: (11), (13), (14) e (15).

\subsubsection{Entropia Condicional}

Outro conceito importante que será usado mais adiante no texto é o de Entropia Condicional. Dado $Y=\left\{y_{1}, y_{2}, \ldots, y_{n}\right\}$ e $X=\left\{x_{1}, x_{2}, \ldots, x_{n}\right\}$ duas variáveis aleatórias e discretas com probabilidades individuais, do conjunto dado por:

$$
\begin{aligned}
p\left(x_{i}\right) & =\operatorname{Pr}\left\{X=x_{i}\right\}, p\left(x_{i}\right) \geq 0, \sum_{i=1}^{n} p\left(x_{i}\right)=1 \\
p\left(y_{j}\right) & =\operatorname{Pr}\left\{Y=y_{j}\right\}, p\left(y_{j}\right) \geq 0, \sum_{j=1}^{n} p\left(y_{j}\right)=1 e \\
p\left(x_{i}, y_{j}\right) & =\operatorname{Pr}\left\{X=x_{i}, Y=y_{j}\right\}, p\left(x_{i}, y_{j}\right) \geq 0, \sum_{i=1}^{n} \sum_{j=1}^{m} p\left(x_{i}, y_{j}\right)=1 .
\end{aligned}
$$

A probabilidade condicional $Y=y_{i}$ dado $X=x_{i}$ é dado por:

$$
\begin{gathered}
p\left(y_{j} \mid x_{i}\right)=\operatorname{Pr}\left\{Y=y_{j} \mid X=x_{i}\right\}, p\left(y_{j} \mid x_{i}\right) \geq 0 \text { para cada } \mathrm{i} \\
\sum_{j=1}^{m} p\left(y_{j} \mid x_{i}\right)=1, \forall i=1,2, \ldots, n
\end{gathered}
$$

Da mesma forma, a probabilidade condicional de $X=x_{i}$ dado $Y=y_{i}$ é:

$$
p\left(x_{i} \mid y_{j}\right)=\operatorname{Pr}\left\{X=x_{i} \mid \mathrm{Y}=y_{j}\right\}, p\left(x_{i} \mid y_{j}\right) \geq 0 \text { para cada } \mathbf{j}
$$




$$
\sum_{i=1}^{n} p\left(x_{i} \mid y_{j}\right)=1, \forall j=1,2, \ldots, m
$$

Para chegar ao conceito de Entropia vamos precisar das seguintes relações:

$$
\begin{gathered}
p\left(x_{i}, y_{j}\right)=p\left(x_{i}\right) p\left(y_{j} \mid x_{i}\right)=p\left(y_{j}\right) p\left(x_{i} \mid y_{j}\right), \\
p(x i)=\sum_{j=1}^{m} p\left(x_{i}, y_{j}\right) \mathrm{e} \\
p(y j)=\sum_{i=1}^{n} p\left(x_{i}, y_{j}\right) \mathrm{e}
\end{gathered}
$$

Com todos esses conceitos estabelecidos podemos definir Entropia Conjunta de $(X, Y)$ como:

$$
H(X, Y)=-\sum_{i=1}^{n} \sum_{j=1}^{m} p\left(x_{i}, y_{j}\right) \log _{2} p\left(x_{i}, y_{j}\right)
$$

Agora para chegar na Entropia Condicional precisamos notar que:

$$
\begin{aligned}
& H(X)=-\sum_{i=1}^{n} p\left(x_{i}\right) \log _{2} p\left(x_{i}\right)=-\sum_{i=1}^{n} \sum_{j=1}^{m} p\left(x_{i}, y_{j}\right) \log _{2} p\left(x_{i}\right) \\
& H(X)=-\sum_{i=1}^{n} p\left(x_{i}\right) \log _{2} p\left(x_{i}\right)=-\sum_{i=1}^{n} \sum_{j=1}^{m} p\left(x_{i}, y_{j}\right) \log _{2} p\left(x_{i}\right)
\end{aligned}
$$

Com isso temos que a Entropia Condicional de $Y$ dado $X=x_{i}$ é dada por

$$
H\left(Y \mid X=x_{i}\right)=-\sum_{j=1}^{m} p\left(y_{j} \mid x_{i}\right) \log _{2} p\left(y_{j} \mid x_{i}\right)
$$

para cara $i=1,2, \ldots, n$. A Entropia Condicional de $Y$ dado $X$ é a média de $H(Y \mid X=$ $x_{i}$ ) ponderada pelas probabilidades $p\left(x_{i}\right)$ :

$$
H(Y \mid X)=-\sum_{i=1}^{n} p\left(x_{i}\right) H\left(Y \mid X=x_{i}\right)=-\sum_{i=1}^{n} \sum_{j=1}^{m} p\left(x_{i}, y_{j}\right) \log _{2} p\left(y_{j} \mid x_{i}\right)
$$




$$
H(Y \mid X)=\sum_{i=1}^{n} p\left(x_{i}\right)\left[-\sum_{j=1}^{m} p\left(y_{j} \mid x_{i}\right) \log _{2} p\left(y_{j} \mid x_{i}\right)\right]
$$

\subsubsection{Propriedades da Entropia de Shannon}

A Entropia de Shannon é uma medida importante para se medir e avaliar estruturas e padrões em conjuntos de dados. O quanto mais baixa a entropia mais estruturas já estão presentes na relação. A utilidade se torna mais óbvia quando se olha algumas propriedades da Entropia de Shannon:

1. $H(x)$ é contínua(16). A prova disso vêm da própria definição, a função $\log (x)$ é contínua para valores positivos e um polinômio de funções contínuas é contínuo, então $H(x)$ é contínua.

2. $H(x)$ é uma função côncava de $P$ em $\Delta_{n}$.

3. $H(x)$ é não negativa:

$$
H(p) \geq 0 \Longleftrightarrow P=P_{0} \text {, onde } P_{0}=(0,0,1,0, \ldots, 0,0) \in \Delta_{n}
$$

4. $H(x)$ é simétrica(16):

$$
H\left(p_{1}, \ldots, p_{n}\right)=H\left(p_{r(1)}, \ldots, p_{r(n)}\right)
$$

onde $r$ é qualquer permutacao entre 1 e $n$.

5. $H=0$ se e semente se $p(s)=1$ para algum $s \in \operatorname{dom}(X)$ e $p(x)=0$ para todos os outros $x \in \operatorname{dom}(X)$. Isso significa que a entropia $H$ só é 0 se estiver certo da saída, ou seja, o sistema é determinado(16).

6. A Entropia de um sistema não se altera mediante a adição de um estado impossível(16).

$$
\begin{array}{r}
p_{n+1}=0 \rightarrow p * \log _{2}(p)=0,0 \log _{2}(0) \equiv 0 \\
H_{n}\left(p_{1}, \ldots, p_{n}\right)=H_{n+1}\left(p_{1}, \ldots, p_{n}, 0\right)
\end{array}
$$


7. Para qualquer número de estados $N=|\operatorname{dom}(X)|$ a entropia $H$ é máxima e igual a $\log _{2}(N)$ se todos os estados de $x \in \operatorname{dom}(X)$ tem igual probabilidade. Essa é a situação onde não se tem nenhuma estrutura na distribuição e é o mais incerto possível(16).

8. Qualquer mudança no sentido de se igualar as probabilidades aumenta-se o $H$. O quanto mais estados tem chances iguais de ocorrer, menos estrutura se tem e maior é a incerteza.

9. A incerteza de duas variáveis independentes $(X, Y)$ é a soma de suas incertezas. Conhecer $X$ não nos da nenhuma informação sobre $Y$, logo a entropia condicional de $Y$ sabendo-se $X$ é igual a entropia de $Y$.

$$
\begin{aligned}
H(X, Y) & =H(X)+H(Y), X e Y \text { independentes } \\
H(Y \mid X) & =H(Y)
\end{aligned}
$$

10. A incerteza de duas variáveis dependentes $(X, Y)$ é menor que a soma das incertezas individuais. Isto é causado pela informação agregada (estrutura) que é dada na correlação das duas variáveis. Por causa da estrutura relacionando $Y$ e $X$, a entropia condicional $Y$ sabendo-se $X$ é menor que a entropia de $Y$.

$$
\begin{aligned}
H(X, Y) & <H(X)+H(Y), X e Y \text { dependentes } \\
H(Y \mid X) & <H(Y)
\end{aligned}
$$

11. As incertezas de duas variáveis $(X, Y)$ é a soma da incerteza de uma variável $X$ a incerteza da variável $Y$ dado $X$. Isto mostra também que a incerteza de uma variável $Y$ nunca aumenta dado o conhecimento de $X$ :

$$
\begin{aligned}
& H(X, Y)=H(X)+H(Y \mid X)=H(Y)+H(X \mid Y) \\
& H(Y \mid X) \leq H(Y)
\end{aligned}
$$

\subsubsection{Transmissão de Informação}

A força da relação entre duas variáveis pode ser mensurada pela Transmissčo de Informação. 


$$
\begin{aligned}
T(X, Y) & =H(X)+H(Y)-H(X, Y) \\
& =H(X)-H(X \mid Y) \\
& =H(Y)-H(Y \mid X)
\end{aligned}
$$

Quando as variáveis $X$ e $Y$ são independentes $T$, seguindo a teoria de Entropia de Shannon descrita anteriormente, assume o valor de 0 e aumenta conforme a relação entre as variáveis aumenta. Nesse sentido, transmissão de informação é um tipo de medida de correlação entre variáveis.

\subsection{Discretização}

Discretização pode ser entendida com o processo de transformar um tipo de dado em outro tipo. Os tipos de dados são "quantitativo" para "qualitativo", "continuo" para "discreto", "ordinal" para "nominal".

Um dado é do tipo Qualitativo quando seus valores podem ser dispostos em categorias seguindo alguma característica mas nenhuma operação aritmética pode ser feita com eles. Exemplos de dados que são considerados do tipo qualitativo são: cores, escolaridades (primário, primeiro grau completo, superior completo, etc), gênero (masculino, feminino), etc.

Um dado do tipo Quantitativo é essencialmente numérico. Eles podem ser ordenados e podem ser alvo de operações aritméticas. Ainda dentro do tipo Quantitativo, ainda podemos subdividir em dois subgrupos: discreto ou contínuo. Um dado Discreto tem valores que podem ser contados, e tem como característica principal que não podem assumir todos os valores em um intervalo. Por exemplo número de televisores numa casa, número de carros de uma pessoa, idade, etc. Os valores do tipo Contínuo podem assumir qualquer valor dentro de um intervalo, por exemplo altura, peso, distância.

Discretização nesse texto será entendido então como o método usado para transformar um conjunto de dados contínuos em um conjunto discreto. Com essa transformação podese disso utilizar métodos de análise discretos (Entropia de Shannon, por exemplo). 


\subsubsection{Discretização por Intervalos de Mesmo Tamanho}

O método mais simples de discretização é o de Intervalos de Mesmo Tamanho, na literatura encontrado também como "Equal Width Discretization" $(E W D)(17)(18)$.

Esse método consiste em se tomar o menor valor $v_{\min }$ e o maior valor $v_{\max }$ do conjunto, subtrair o menor do maior e dividir esse intervalo em $k$ pedaços iguais de tamanho $w$ onde $\left.w=\left(v_{\max }-v_{\min }\right) / k\right)$. Cada corte no subconjunto fica sendo no ponto $v_{\min }+w, v_{\min }+$ $2 * w, \ldots, v_{\min }-(k-1) w$

A escolha de $k$ é muito importante para se manter alguma consistência nos dados do conjunto. Se $k$ for um numero muito pequeno pode-se perder muito da informação que estava presente nesse conjunto. Por outro lado, se o valor de $k$ é muito grande, a discretização pode acabar não sendo útil por gerar um número elevado de classes com poucos elementos em cada uma.

Após a determinação dos intervalos, é necessário escolher um representante para cada um deles. Normalmente toma-se a mediana.

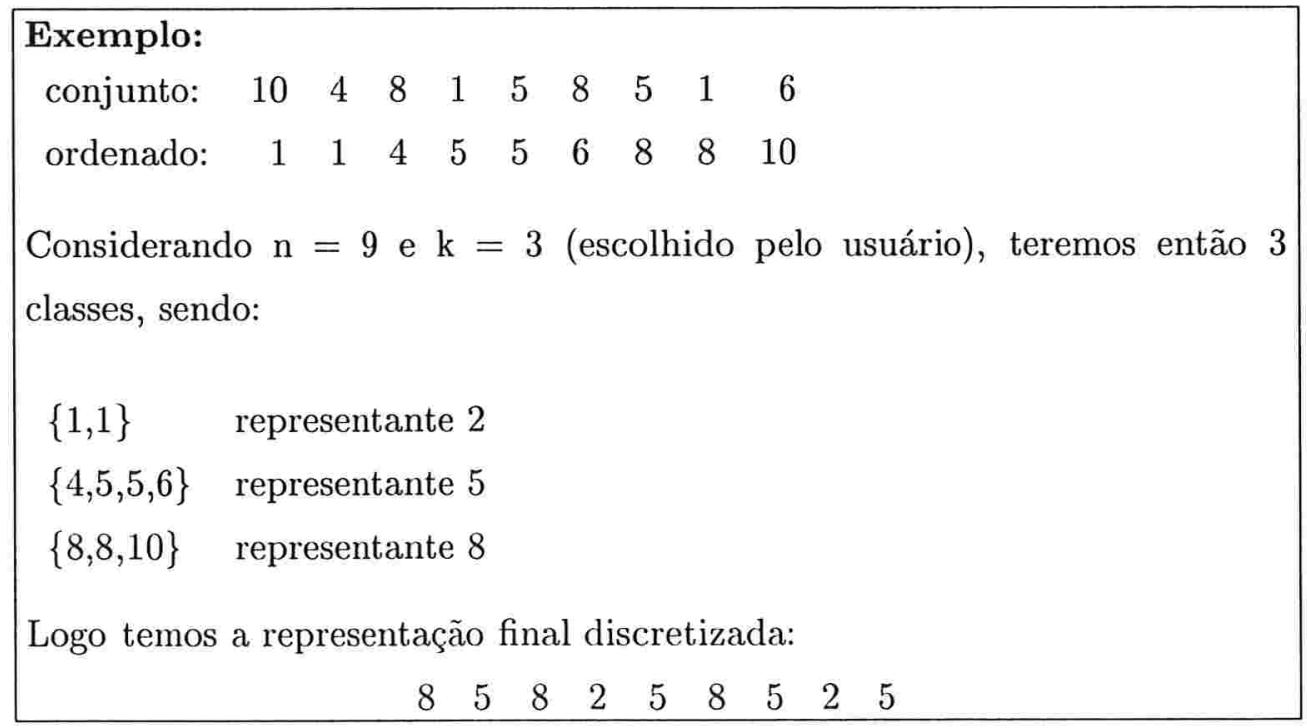

O método EWD é o mais simples, mas sofre do problema de perda de informação agregada aos dados. Esse problema se deve ao fato de $k$ ser escolhido sem nenhuma referência as propriedades do conjunto sendo discretizado. 


\subsubsection{Discretização por Intervalos de Mesma Freqüência}

A discretização com intervalos de mesma freqüência, EFD ("Equal Frequency Discretization") divide os valores, já ordenados, em $k$ intervalos, deixando assim cada intervalo com um número quase igual de elementos.

O valor de $k$ é definido pelo usuário e cada intevalo irá conter, aproximadamente, $n / k$ elementos. Vale notar que elementos com valores iguais têm que ficar no mesmo intervalo.

A escolha do representante de cada intervalo é igual à do método EWD, por exemplo a mediana.

Para o exemplo vamos usar o mesmo do método EWD, com os mesmos parametros:

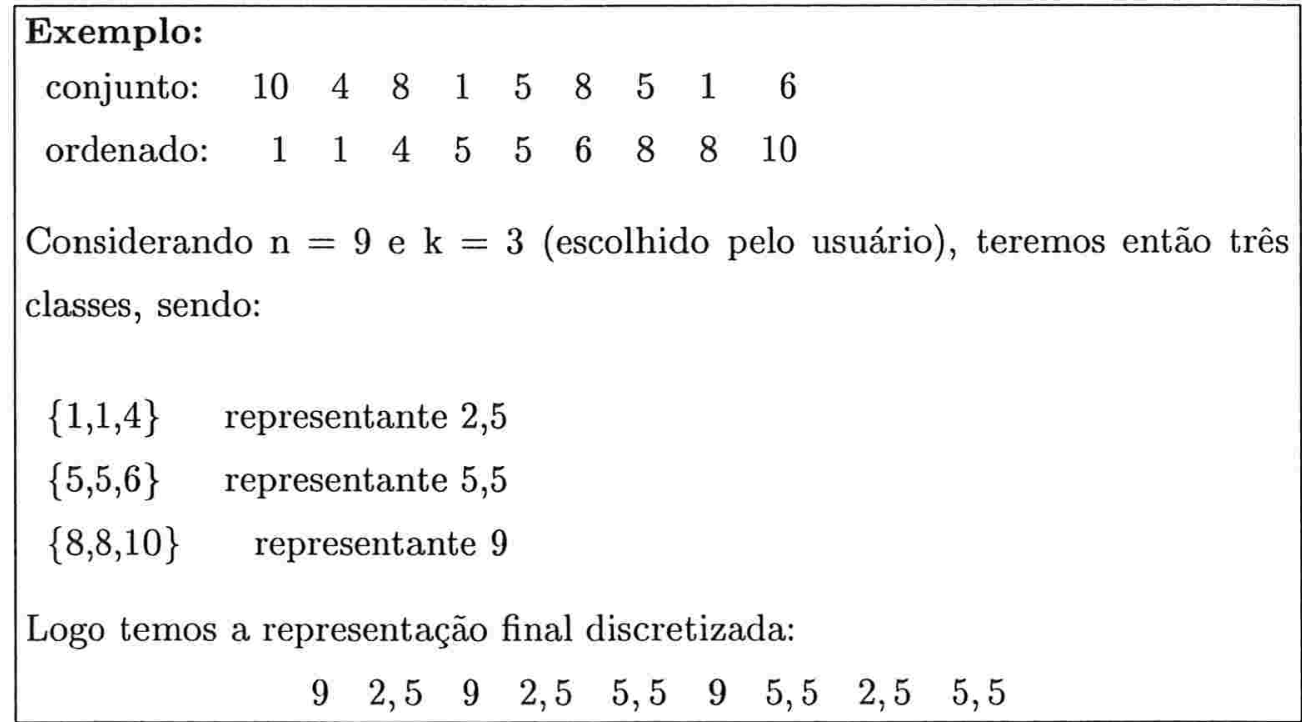

A discretização EFD tem como objetivo principal criar classes, separando os valores em conjuntos de tamanho parecido.

\subsubsection{Discretização Baseada em Entropia}

O método de Discretização Baseado em Entropia segue a idéia da heurística de entropia mínima que foi proposto por Fayyad e Irani (19).

Esse algoritmo escolhe os cortes para criação das classes baseado no conceito de ganho de informação a cada corte possível. Os cortes possíveis são escolhidos a partir de um conjunto de dados de suporte. 
Um exemplo possível dos dados necessários (já ordenados):

\begin{tabular}{ccc|c|c|cc|c|ccccccc}
$\mathrm{X}$ & $\mathrm{X}$ & $\mathrm{X}$ & $\mathrm{Y}$ & $\mathrm{X}$ & $\mathrm{Y}$ & $\mathrm{Y}$ & $\mathrm{X}$ & $\mathrm{Y}$ & $\mathrm{Y}$ & $\mathrm{Y}$ & $\mathrm{Y}$ & $\mathrm{Y}$ & $\mathrm{Y}$ & $\mathrm{Y}$ \\
\hline 3 & 6 & 7 & 14 & 17 & 19 & 25 & 35 & 38 & 49 & 52 & 53 & 58 & 60 & 61
\end{tabular}

Dado um conjunto $S$, uma variável a ser discretizada $A$ e um corte $T$, a entropia de classe criada por $T$, que chamaremos de $E(A, T ; S)$ será:

$$
E(A, T ; S)=\frac{\left|S_{1}\right|}{|S|} H\left(S_{1}\right)+\frac{\left|S_{2}\right|}{|S|} H\left(S_{2}\right)
$$

Lembrado que $H\left(S_{1}\right)$ e $H\left(S_{2}\right)$ são as entropias das partições $S_{1}$ e $S_{2}$ respectivamente, seguindo a definição de entropia (equação 2.1).

$\mathrm{O}$ corte $T_{\min }$ é aquele que minimiza a função de entropia da classe sobre todas as possibilidades de corte dentre os possíveis seguindo o conjunto suporte. O método então continua sendo aplicado recursivamente para as duas partições que $T_{\min }$ criou até que uma condição de parada seja alcançada, criando assim os intervalos (bins). Seguindo a idéia proposta por Fayyad e Irani, será usado o Princípio de Descrição de Comprimento Minimal ("Minimal Description Length Principle, MDLP") como critério de parada da estratégia de discretização recursiva. A idéia por trás do conceito de MDLP, de forma bem resumida, é que qualquer regularidade em um conjunto de dados pode ser usado para compactar esse conjunto, ou seja, descreve-lo de forma mais simples(20).

A procura por novos cortes nesse algoritmo irá parar de particionar o conjunto $S$ se e somente se:

$$
\operatorname{Ganho}(A, T ; S)<\frac{\log _{2}(N-1)}{N}+\frac{\delta(A, T ; S)}{N} .
$$

onde $N$ é o número de elementos no conjunto $S$,

$$
\begin{gathered}
\operatorname{Ganho}(A, T ; S)=H(S)-E(A, T ; S), \\
\delta(A, T ; S)=\log _{2}\left(3^{k}-2\right)-\left(k * H(S)-k_{1} * H\left(S_{1}\right)-k_{2} * H\left(S_{2}\right)\right),
\end{gathered}
$$

$k_{1}$ é o número de elementos distintos do subconjunto $S_{1}$ e analogamente para $k_{2}$.

Como cada corte é feito é avaliado de acordo com o critério de uma forma independente das outras partições, poderá acontecer de algumas partes do conjunto $S$ ficarem particionadas de uma forma mais fina enquanto outros ficaram mais esparsas. 


\subsection{Mineração de Dados — Data-mining}

Ao longo das três últimas décadas, muitas empresas e organizações vem gerando grandes quantidades de dados armazenadas em arquivos e bancos de dados. Para processar todos esses dados se tem à disposição toda a tecnologia de Bancos de Dados e a linguagem estruturada $S Q L$, que facilitam a busca e a organização dos dados.

"A Computadorização da vida diária tem causado a coleta e o armazenamento de comportamento individual por bancos, companhias de cartões de credito, sistemas de reserva e pontos de venda eletrônicos" (21). Com isso, a quantidade de dados é tão grande que fica impossível para os humanos examinarem tudo. Sem o suporte computacional , a maioria dos dados coletados permaneceria não observado. O nome desse suporte computacional é Mineração de Dados.

Mineração de Dados significa descobrir informações novas utilizando-se de padrões e regras em grandes quantidades de dados. Para tanto, são utilizas técnicas de diversas áreas como Estatística, Redes Neurais, Algoritmos Genéticos e de Aprendizado Computacional ("Machine Learning") e ainda Bancos de Dados Relacionais de Alto Desempenho. A perspectiva de análise automática oferecida pelas técnicas de Mineração de Dados vão além da análise de eventos passados, pode no entanto ajudar a responder perguntas que tradicionalmente antes levavam muito tempo para serem respondidas.

Com esse tipo de tecnologia as empresas poderão focar suas forças nos dados mais importantes, podendo prever comportamentos, descobrir padrões de consumo, analisar novos mercados. No ramo da saúde campanhas de vacina podem ser melhor planejadas tal como criação de remédios mais eficientes. A maioria das companhias já armazenam e refinam grandes quantidades de informação, logo as técnicas de Mineração de Dados podem ser implementadas rapidamente em plataformas de software já existentes, aumentando assim o valor dos dados já existentes. Quando utilizado junto com computadores de alto processamento ou de processamento paralelo, as ferramentas de mineração de dados podem analisar enormes quantidades de dados, podendo assim responder perguntas do tipo: "Quais clientes estão mais propensos para responder a minha próxima campanha e por quê?". 


\subsubsection{Objetivos de Mineração de Dados}

O nome "Mineração de Dados" vem da semelhança em se procurar por dados importantes em grandes Bancos de Dados com a de se procurar em uma montanha um veio de minério valioso. Ambos necessitam passar por um imenso amontoado de material. Com bancos de dados de tamanho suficiente, a tecnologia de mineração de dados pode gerar novas oportunidades comerciais disponibilizando as seguintes capacidades:

Previsão automática de comportamentos e tendências - Mineração de Dados automatiza o processo de encontrar dados que possam ser interpretados como informações úteis em grandes Bancos de Dados. Perguntas que normalmente iriam necessitar de extenso trabalho braçal podem ser agora respondidas diretamente a partir dos dados de uma forma rápida. Exemplo típico de problema de previsão é o de encontrar mercado alvo. Utilizando-se de dados de campanhas passadas, pode-se identificar o público alvo com maior chance de se responder a uma nova campanha, maximizando assim um investimento.

Descoberta automática de padrões previamente desconhecidos - Ferramentas de mineração de dados podem percorrer bancos de dados e identificar padrões previamente desconhecidos. Um exemplo de descobrimento de padrão é a análise de dados de vendas em uma loja para identificar produtos aparentemente não relacionados que são comprados juntos com uma certa freqüência. Outro exemplo de reconhecimento de padrão é detectar transações de cartão de crédito fraudulentas.

Classificação - Mineração de Dados pode particionar os dados de tal forma que classes ou categorias diferentes possam ser identificadas baseados em combinações de parâmetros. Por exemplo os consumidores de um supermercado podem ser classificados de acordo com seus hábitos de compra (cliente infreqüentes, cliente fiel, cliente que só compra durante promoções); esse tipo de classificação pode ser usada em diferentes analises das transações de compra de clientes.

Otimização - Um objetivo eventual pode ser o de otimizar o uso de recursos limitados tal como tempo, espaço, dinheiro ou materiais e maximizar os resultados como vendas e lucros dentro de um conjunto de restrições. Nesse sentido mineração de dados se assemelha à função objetivo usada em problemas de otimização sobre restrições. 


\subsubsection{Tipos de Conhecimento Descobertos com Mineração de Dados}

O conhecimento descoberto através de mineração de dados pode ser separado em cinco tipos (22):

Regras de Associação - essas regras correlacionam a presença de um conjunto de elementos com outra escala de valores para outro conjunto de variáveis. Por exemplo, quando uma mulher compra uma bolsa, ela provavelmente irá comprar também um par de sapatos.

Classificação Hierárquica - O objetivo é trabalhar com um conjunto já existente de eventos e criar uma hierarquia de classes. Por exemplo, uma população pode ser dividida em cinco grupos de acordo com a renda mensal.

Padrões Seqüenciais - uma seqüência de ações ou eventos é percebida. Por exemplo, se um consumidor compra uma câmera digital, ele irá em alguns meses comprar mais um cartão de memória para câmera e pilhas recarregáveis.

Padrões em séries históricas - semelhanças podem ser detectadas dentro dos pontos de uma série histórica. Por exemplo, As ações de uma empresa de utensílios domésticos e de uma empresa de desenvolvimento de software mostraram o mesmo padrão em termos de preço de fechamento durante o ano de 2000.

Categorização e Segmentação - uma dada população de eventos ou itens pode ser particionada (segmentada) em conjuntos de elementos "similares". Por exemplo, uma coleção de dados sobre um tratamento de uma doença pode ser dividida em grupos, baseado nas semelhanças quanto aos efeitos colaterais.

\subsubsection{Perigos ao se usar Mineração de Dados}

Como já mencionado anteriormente, Mineração de Dados tem o objetivo de achar hipóteses a partir dos dados, logo, os resultados desse processo são apenas hipóteses e como tal devem ser tratadas com cuidado para se evitar má interpretação dos resultados.

Dentre os pontos que podem levar a uma interpretação errada dos dados está, por exemplo, em se entender uma relação encontrada como uma relação de causa e efeito. $\mathrm{O}$ 
que pode ter acontecido é que os dados mostraram um relacionamento entre as variáveis, mas não quer dizer que isso vai acontecer sempre já que essa informação foi tirada dos dados e não deduzida; esses dados podem ser fruto de pré-seleção, não mostrando exatamente o cenários real do mundo. Um exemplo disso são os questionários, raramente respondidos por uma amostra aleatória da população.

Outro ponto importante é o de se tomar a parte pelo todo. Quando se faz uma projeção nos dados, pode acontecer de alguma relação importante se perder e no resultado final obtermos uma hipótese que leve ao erro se não for analisada também se tendo idéia do todo.

Conclui-se que ao se ter um resultado da Mineração de Dados, ainda assim análise deve ser feita sobre as hipóteses encontradas e perceber quais podem ser realmente válidas e quais foram apenas resultado da má coleta dos dados. Essa análise têm que ser feita por alguém que conheça a massa de dados, e tenha senso crítico bom o suficiente pra julgar as hipóteses obtidas. 


\section{Trabalhos Relacionados}

A motivação para o desenvolvimento do software Entrop Calc foi criar uma ferramenta útil e simples de ser usada que possa colaborar com pesquisadores de diversas áreas do conhecimento na análise de seus conjuntos de dados.

A contribuição desse projeto está justamente no fato de não se ter uma ferramenta simples e fácil para o cálculo de entropia, que permita visualização dos resultados de forma iterativa e rápida. Todos os software que podem fazer o cálculo não são específicos para isso e a entropia é apenas mais uma funcionalidade; logo, em muitos casos, sua utilização acaba não sendo muito simples, necessitando muitas vezes de um conhecimento muito específico do software.

Dentre os software que podem ser usados para calcular a entropia de alguma forma, podemos separá-los em quatro grupos, por terem características semelhantes: Software de cálculo científico, Software de cálculo estatístico, Calculadoras simples para projetos específicos e Software específico de aprendizado computacional e mineração de dados.

\subsection{Software Específicos de Cálculo Científico}

Quando se pensa em software que ofereça funcionalidades matemáticas, logo se pensa no Matlab, Scilab, Mathematica, Maple e até mesmo o Excel no universo Windows. Esses softwares são excelentes em termos de eficiência e funcionalidade, mas para o cálculo de entropia, é necessário um conhecimento mais aprofundado de cada software para poder ser feito.

O Matlab é um pacote comercial de manipulação de matrizes que funciona como um ambiente de programação interativa.

A linguagem de programação do Matlab é excepcionalmente direta, já que todos 
objetos são considerados vetores. Tem ainda um suporte gráfico para mostrar resultados numéricos. O Matlab aceita executar comandos colocados em um arquivo, como um arquivo de "script". A linguagem tem todas as diretivas básicas de uma linguagem de programação como if, for, while e ainda permite fazer recursões.

Existem na internet algumas implementações da entropia de Shannon na linguagem do Matlab, tal como o cálculo de discretização. Esse código é aberto e pode ser alterado como for necessário para uso próprio, facilitando então a implementação de funções de análise baseadas em entropia.

O Scilab é também um pacote de software para cálculo numérico e disponibiliza um ambiente poderoso para aplicações de engenharia ou científicas. Tem distribuição livre e código aberto disponível na internet desde 1994. Um de seus objetivos é ser um Matlab gratuito, logo suas funcionalidade acabam sendo bastante parecidas.

Em sua biblioteca, o Scilab, dispõem de muitas funções matemáticas e ainda a possibilidade de adicionar interativamente mais funções feitas em outras linguagens como C e FORTRAN. Também tem uma linguagem de programação muito parecida com a do Matlab.

Dentre as ferramentas pagas para cálculo matemático ainda temos o software Maple e o Mathematica que são concorrentes e tem funcionalidades semelhantes. Um ponto interessante em comum deles é a capacidade de conseguir resolver equações literais, integrais e derivadas. Em termos de apresentação mostram gráficos, desenham figuras a partir de equações e permitem análise gráfica. Ambos tem uma linguagem de programação e ainda uma interface gráfica bem elaborada

O Excel é a planilha eletrônica que vem junto com o Microsoft Office. Mesmo não sendo um software específico para cálculos matemáticos científicos, têm algumas ferramentas que podem ser bem úteis, como por exemplo, o pacote de análise de dados que faz a discretização simples (EWD) e ainda mostra um histograma. Uma facilidade que o Excel traz é a manipulação de dados, fazendo com que fique muito simples a aplicação de várias funções matemáticas a eles. Outra funcionalidade útil é a integração com os outros software do Office, facilitando a confecção de relatórios e apresentações.

É muito comum se encontrar várias soluções no formato de planilhas eletrônicas do Excel no universo financeiro, em bancos por exemplo. Isto se deve ao fato de sua linguagem, VB Script ser extremamente fácil de ser aprendida e usada. Com essa facilidade, 
vem uma falta de flexibilidade inerente. Em último caso se pode usar a API do Excel, em formato COM, através de uma aplicação em $\mathrm{C}++$ por exemplo, mas isso é muito mais complicado do que simplesmente fazer um módulo em VB Script.

Em todos os casos não há, pelo menos na distribuição oficial, o cálculo de entropia e muito menos um mecanismo de análise como o proposto pelo EntropCalc. Para se obter o cálculo de entropia, seria necessário a implementação dessa funcionalidade através de funções ou módulos usando a linguagem específica de cada um dos softwares mencionados, dificultando bastante o trabalho para um especialista de uma área diferente de Computação.

Nessas condições, o Entrop Calc acaba sendo mais útil para o que se propõem, pois disponibiliza um ambiente completo para análise por entropia dos conjuntos de dados, sem necessidade de aprendizado de uma linguagem de programação específica. Outra vantagem é a visualização dos resultados que é muito mais simples de ser entendida e analisada, facilitando ainda mais o trabalho do pesquisador.

\subsection{Software Específicos de Cálculo Estatístico}

Este tipo de software acaba sendo bem específico, não tendo tantas funcionalidades quanto os software mencionados na seção anterior. Suas funcionalidades são focadas no mundo da estatística, funcionalidades estas que teriam, em muitos casos, que ser desenvolvidas pelo próprio usuário atrasando e dificultando a obtenção de resultados de análises.

Dentre os software mais populares nessa área temos o S, S-PLUS e o R.

O S é o software "original" ou precursor dos três, de acordo com seu site oficial (http://cm.bell-labs.com/cm/ms/departments/sia/S/index.html), é uma linguagem e uma ferramenta de organização, visualização e análise de dados. Contém um grande número de funcionalidades estatísticas e um ambiente interativo de análise. A linguagem e suas bibliotecas foram desenvolvidas no Bell Labs como resultado de suas pesquisas em computação estatística começada no final da década de 70. Desta linguagem surgiram o S-PLUS e o R.

A linguagem S é orientada a objetos e tem o objetivo de "programar para os dados", ou seja, descrever para o computador como mostrar um gráfico, gerar um relatório ou 
montar um modelo estatístico. Apesar de ser um software que pode ser usado por si só, tem uma ênfase em usuários que queiram criar um software a partir de novas idéias. Sua linguagem de programação simples de ser usada é que permite a facilidade e possibilidade do usuário escrever seu próprio pacote de funcionalidades.

A partir de 1993 a licença de uso da linguagem S se tornou exclusiva da MathSoft, com isso, apenas a MathSoft poderia vender produtos que utilizassem a linguagem S. Dessa forma, o S passou a ser disponível apenas através do S-PLUS.

O S-PLUS incorporou a linguagem $\mathrm{S}$ e mais diversas ferramentas de visualização e tratamento de dados, montando um arcabouço de análise estatística muito completo. Fornece uma interface para integração com Microsoft Power Point e até mesmo com o Excel. Além disso ainda disponibiliza uma ferramenta de criação de relatórios facilitando a visualização de resultados. Consegue lidar com gigas de dados sem a necessidade de ler todo o conjunto para a memória, para tanto utiliza a idéia de ir lendo os dados à medida que são utilizados.

Ainda nessa mesma linha de software temos o $\mathrm{R}$ que é uma versão do $\mathrm{S}$ que segue a licença GPL de software. O R é um conjunto de aplicações integradas, dentre elas: uma linguagem, muito parecida com a do S, um ambiente de execução com capacidade gráfica, uma ferramenta para depuração, acesso a algumas funcionalidades do sistema e além disso ainda se pode executar programas presentes em arquivos de script.

$\mathrm{O} R$ é uma linguagem interpretada que permite o uso de condicionais(if), laços (for, while) e programação modular. Todas as funções visíveis ao usuário foram escritas em R. O usuário pode também utilizar funções escritas em C, C++ e FORTRAN caso precise de maior desempenho.

Ambas as linguagens, S e R, têm cálculo de entropia no seu conjunto de funções padrão. A entrada de dados não é muito complicada e a visualização pode conter gráficos que facilitem a análise. É difícil fazer uma comparação entre o Entrop Calc e o S ou o R já que o Entrop Calc é uma ferramenta de análise e ambas as outras são linguagens linguagens de programação. Para chegar ao resultado obtido com o Entrop Calc seria necessário escrever um script com a série de cálculos necessários e mesmo assim não teria tanta facilidade em navegar pelos resultados, facilidade esta que é um dos objetivos do EntropCalc. O S-PLUS apesar de ser $u$ m ambiente muito completo, é um software pago e não com o mesmo fóco do Entrop Calc, logo, é possível fazer o mesmo tipo de 
análise com entropia, mas sem a mesma facilidade.

\subsection{Calculadoras Simples para Projetos Específicos}

Existem ainda muitas outras calculadoras de entropia na internet para diversos fins, mas com implementações bem mais simples, como por exemplo a Diversity Calculator (http://www-2.cs.cmu.edu/ trb/java/Dcalc/). Ela é um applet que calcula entropia com o objetivo de analisar diversidade de grupos dentro de uma população. Foi utilizada na tese de doutorado de Tucker Balch - "Behavioral Diversity in Learning Robot Teams". O conceito é muito parecido com o do Entrop Calc, mas com bem menos recursos. Basicamente ele só calcula a entropia e mostra o valor, não se pode fazer nenhum tratamento desses dados, nem analisar resultados parciais, nem ler os dados em um arquivo, nem ter um arquivo de saída com os resultados.

Outro exemplo é uma calculadora muito simples que foi usada para estudar a visão de pombos (http://www . pigeon.psy.tufts .edu/avc/young/entropy.html) . Basicamente só calcula a entropia de um vetor de 16 posições (categorias) onde em cada posição se coloca a freqüência que ocorre aquela categoria. Este exemplo também é um applet.

Em ambos os casos temos bons exemplos de como a utilização do Entrop Calc seria muito útil, evitando um trabalho desnecessário dos pesquisadores em desenvolver essas ferramentas, deixando apenas a preocupação na análise dos dados.

\subsection{Software Específico de Aprendizado Computaci- onal e Mineração de Dados}

Um trabalho relacionado muito interessante é o WEKA (Waikato Environment for Knowledge Analysis) (23), que é uma ferramenta muito completa para Mineração de Dados e Aprendizado Computacional desenvolvida na Universidade de Waikato na Nova Zelândia.

O WEKA é todo feito em Java e tem uma interface uniforme para a utilização de todas as técnicas implementadas. O objetivo principal é criar um ambiente para o desenrolvimento de técnicas de Aprendizado Computacional e Mineração de Dados e a partir dai aplicá-las aos problemas da vida real. Ele ainda têm 1 m conjunto de ferramentas 
para pré-processamento dos dados e ambiente para comparar algoritmos de Aprendizado Computacional.

Com a utilização do WEKA, um pesquisador especialista em uma área em particular poderá usar as técnicas de Aprendizado Computacional para conseguir derivar informações úteis a partir de seus conjuntos de dados.

Os objetivos do WEKA são:

1. Disponibilizar as técnicas de Aprendizado Computacional de uma forma razoavelmente fácil.

2. Aplicar as técnicas implementadas a problemas reais.

3. Desenvolver novas técnicas de Aprendizado Computacional e disponibilizá-las ao mundo.

4. Contribuir com um arcabouço teórico para a área de Mineração de Dados e Aprendizado Computacional.

Da mesma forma que o Entrop Calc, é necessário um especialista nos dados para analisar os resultados, e também funciona a partir de um modo gráfico, facilitando o uso para pessoas mais leigas em computação, já que o público alvo dessas aplicações são usuários especialistas em alguma área e não necessariamente computação.

A diferença do WEKA para a nossa proposta está na análise dos dados utilizando Entropia e Ganho de Informação de uma forma mais simples. Essas duas propostas fazem parte da implementação oficial do WEKA mas é necessário um conhecimento mais aprofundado de teoria. O Entrop Calc foi elaborado para ser o mais simples possível. Com isso o público alvo do nosso projeto, que são pesquisadores de diversas áreas, não necessitarão ter uma preparação mais aprofundada sobre os conceitos que estão usando. A interface do Entrop Calc é simples de ser entendida e manipulada e muito intuitiva, facilitando assim a sua utilização. 


\section{$4 O$ Software}

O objetivo desse projeto foi implementar uma ferramenta que possa ajudar o pesquisador a fazer analises em seus conjuntos de dados utilizando o conceito de Entropia e Quantidade de Informação. A ferramenta tem que ser fácil de ser usada e de entender os resultados obtidos tal como também precisa ser eficiente e robusta.

O produto final foi o software Entrop Calc que pode ser visto na figura 1.

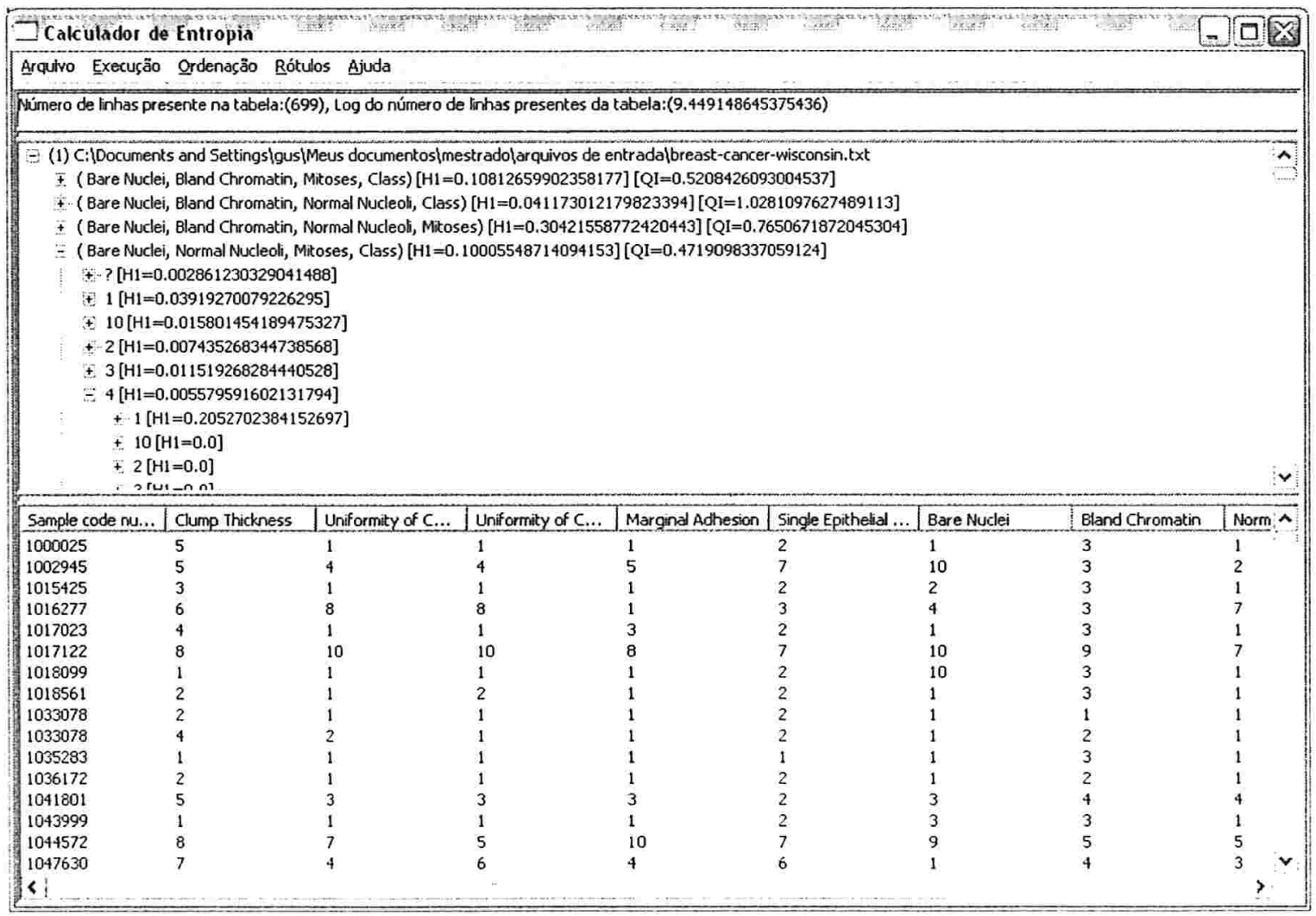

Figura 1: Tela do produto final 


\subsection{História do Desenvolvimento}

A primeira versão do Entrop Calc foi desenvolvida em $\mathrm{C}++$, utilizando o arcabouço Visual Studio 6 da Microsoft.

Fazer uma interface gráfica no Visual Studio é muito simples, basta arrastar o componente desejado para o ponto certo da caixa de diálogo e pronto, um método conhecido como "WYSIWYG" "What You See Is What You Get", em português: O que você vê é o que você têm). Esse método foi muito eficiente para a confecção do protótipo inicial. A partir dele, muitas idéias de como seriam as estruturas internas já foram sendo testadas, mostrando assim se tinham sido boas escolhas ou não.

O maior problema depois de se ter o protótipo pronto e funcional era migrá-lo para outro sistema operacional. Na época, o objetivo maior era uma ferramenta para pesquisadores que usavam o Linux como sistema operacional. Apesar da facilidade de se fazer o protótipo, o problema de se migrar um código totalmente desenvolvido para Windows, utilizando bibliotecas específicas da Microsoft acabava sendo tão grande que acabou não valendo a pena tentar aproveitar o código já escrito.

Nesse ponto a solução seria escolher uma biblioteca gráfica que pudesse ser migrada de Linux para Windows e vice versa sem muitos problemas, com isto poderia continuar desenvolvendo em Windows e apenas recompilar e testar no Linux quando necessário. Esta idéia seria muito trabalhosa, seria necessário aprender mais uma API gráfica e teria que se redesenvolver quase tudo em $\mathrm{C}++$ usando somente a STL, que é padrão entre sistemas operacionais, evitando a incompatibilidade que a MFC (Biblioteca de classes $\mathrm{C}++$ da Microsoft, "Microsoft Foundation Classes") tem por ser específica para Windows.

Levando-se em conta o fato que muitas das classes teriam que ser reescritas e seria necessário utilizar uma API gráfica nova, surgiu então a idéia de desenvolver a aplicação em Java, mesmo contrariando o sentimento geral de que esta linguagem não é adeqüada para a construção de aplicações matemáticas ou que precisem de um desempenho maior.

Porém, com o avanço da tecnologia do Java e a utilização dos "just-in-time compiler" (24) poderia ser possível conseguir um desempenho próximo do que conseguiríamos com $\mathrm{C}++$, talvez não seja possível ainda um desempenho tão bom quanto o que poderia se ter com C ou FORTRAN, mas o ganho que temos com a portabilidade do Java já vale pelo pouco desempenho extra que seria possível. 
Ainda faltava escolher um ambiente para o desenvolvimento do software, um que permitisse navegar pelas classes do projeto, editá-las com facilidade, permitisse a utilização de um programa de depuração, tivesse uma ferramenta de refactoring, tivesse um ambiente de desenvolvimento fácil de interfaces gráficas e fosse gratuito.

A primeira idéia foi usar o Emacs, mas apesar de ser um excelente editor de texto, utilizá-lo para desenvolver projetos com muitas classes e arquivos acaba não sendo muito eficiente. Faltam muitas das ferramentas e funcionalidades que são necessárias, de uma forma integrada, para um desenvolvimento rápido e eficiente de software.

Um ambiente que supria todas essas necessidades é o Eclipse (25). O Eclipse é um ambiente de desenvolvimento de software feito em Java, que traz todas as qualidades dos maiores ambientes de desenvolvimento comerciais mas com um ponto forte a seu favor: é gratuito e com o código fonte aberto. Pode ser customizado de diversas formas desde estilo de programação, até menus, cores e caso ainda não fique como se deseja, em último caso ainda se pode alterar seu código fonte já que ele é aberto e deixar o ambiente como bem entender. Tem um ótimo desempenho, não atrapalhando a dinâmica do desenvolvimento, e uma visualização simples e fácil do projeto, ajudando assim a organizar melhor as idéias e a implementação.

O Entrop Calc foi então desenvolvido em Java (versão 1.5.0_01) dentro do arcabouço Eclipse (versão 3.0). Parte do desenvolvimento foi em Windows XP e parte no Linux (Debian, kernel 2.4.18-1-k7) da rede eclipse do IME.

\subsection{Implementação Matemática}

O Entrop Calc implementa três tipos de cálculo de entropia e mais três discretizações. A parte da apresentação das entropias foi o que acabou dando mais trabalho pela metodologia usada.

Para o cálculo de entropia foi implementada uma estrutura interna de árvore para representar cada combinação de variáveis que precisam ser calculadas.

Cada nó da árvore tem a seguinte estrutura:

// rótulo do nó

String m_s_label; 


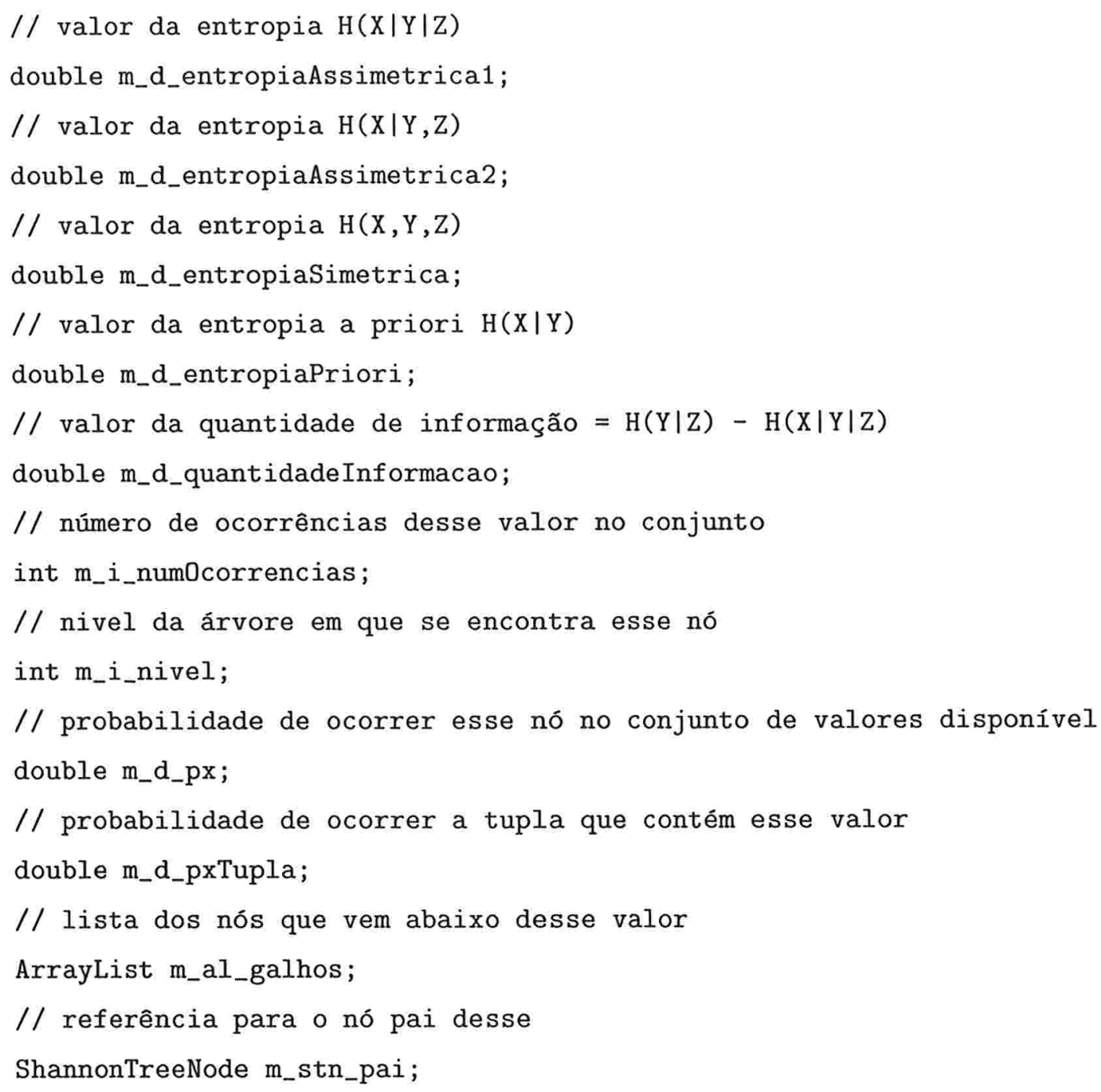

A princípio, tentou-se criar a árvore de apresentação utilizando-se o componente Tree e inserindo todos os treeitens um a um, seguindo a estrutura já montada para o cálculo. Essa idéia apesar de ser funcional, ficava muito lenta. Quando era necessário criar muitos nós (mais de mil) a aplicação ficava alguns minutos travada criando os componentes individualmente. Esse problema não era aceitável, foi então que com um estudo aprofundado da biblioteca JFace, surgiu o conceito de Viewers.

Um Viewer é uma classe na qual, dado um modelo (estrutura de dados), consegue-se mostrar essa estrutura na tela de forma rápida e mais eficiente do que a implementação direta do modelo utilizando-se os controles básicos disponíveis.

Foi utilizado então a classe TreeViewer que é um Viewer especial para se mostrar árvores a partir de uma estrutura interna pronta. Para essa classe saber o que mostrar em cada nó e "entender" a estrutura interna já pronta, foi necessário implementar mais 
duas classes, uma que fosse uma implementação da interface ITreeContentProvider que contém a lógica de como se caminhar pelos nós da árvore modelo, e uma implementação da interface ILabelProvider que se encarrega de escolher qual rótulo vai em cada nó a partir da árvore modelo. Com essas classes implementadas e o modelo pronto, o resto das funcionalidades da árvore como o preenchimento dos galhos, expansão de nós, etc, ficou a cargo do Java. Esse método facilitou bastante o trabalho, evitando preocupações desnecessárias com a confecção da árvore, deixando assim mais tempo para implementação de novas funcionalidades e ainda deixou a apresentação muito mais rápida. O motivo dessa velocidade, é que, o TreeViewer se utiliza de uma técnica chamada lazy evaluation, ou seja, só cria os nós da árvore quando é realmente necessário mostrá-lo, diferente da implementação anterior onde todos os nós eram criados independentemente se iriam sequer ser mostrados ou não.

A mesma idéia de Viewers foi utilizada na confecção da tabela com os dados de entrada. Com isso foi possível implementar a ordenação de colunas de forma extremamente fácil. A classe utilizada foi a TableViewer. Para a ordenação foi utilizada uma classe que extende a classe ViewerSorter e se sobrescreve apenas o método compare. A mesma idéia foi usada no TreeViewer permitindo as diversas possibilidades de ordenação que foram propostas.

\subsection{Implementação Gráfica}

Existem três API's de desenvolvimento de interfaces gráficas para Java, sendo elas AWT, Swing e SWT.

AWT que é a sigla para "Abstract Window Toolkit" é aparte das classes fundamentais do Java e é a API antiga parạ desenvolvimento de interfaces gráficas. AWT usa os componentes nativos da plataforma em que esta rodando a aplicação. Tem a desvantagem de criar aplicações com uma aparência amadora.

Swing é a API de desenvolvimento de interfaces gráficas nova que veio para substituir a API antiga e pouco flexível AWT. Swing é todo desenvolvido em Java e todos os controles são emulados dessa forma. Uma vantagem disso é que a aplicação final tem a mesma aparência e comportamento em qualquer plataforma que for executada. Uma dasvantagem é que, pelo fato do Swing ter que emular cada componente do dialogo, acaba sendo mais lenta que a AWT. 
SWT (Standard Widget Toolkit) é uma biblioteca gráfica desenvolvida pela IBM para ser usado na criação da plataforma Eclipse. Os controles disponibilizados pelo SWT são como os componentes nativos dos sistemas em que executa. Apesar de haver uma grande integração com os componentes nativos, a API ainda continua independente do sistema operacional. SWT é como uma camada de tradução dos componentes gráficos nativos do sistema operacional para o Java. Em nível mais alto, também como parte da plataforma Eclipse, existe ainda a JFace. Esta é uma biblioteca gráfica implementada usando SWT que simplifica tarefas comuns na programação de interfaces gráficas. SWT e JFace trabalham juntos na construção da interface gráfica do usuário.

A estratégia do projeto SWT é construir uma biblioteca simples que produzisse aplicações gráficas acopladas ao ambiente nativo que estivesse rodando. Alguns controles comuns como rótulos, tabelas e listas são deixados a cargo dos componentes nativos, da mesma forma que o AWT, já componentes mais sofisticados, são emulados em Java, seguindo então a idéia do Swing, por exemplo, as barras de ferramentas são emuladas quando usadas no ambiente Motif.

A escolha feita para o desenvolvimento Entrop Calc foi o SWT apenas pelo fato de ser a biblioteca padrão do Eclipse, e esse seria o ambiente de desenvolvimento da aplicação.

\subsubsection{Menus}

A tela principal do Entrop Calc consiste de uma barra de menus de opções (Arquivo, Execução, Ordenação, Rótulos e Ajuda), um rótulo que mostra o número de linhas do arquivo de entrada e o valor da entropia máxima para este número, e ainda um espaço para a visualização da árvore com os cálculos de entropia e uma tabela com os dados do arquivo de entrada sendo analisado.

Através dos menus que se pode fazer a maioria das ações de controle de visualização e de execução do Entrop Calc. Cada menu é o mais intuitivo possível e tem uma tecla de atalho respectiva para cada item e sub-ítem de menu, facilitando a utilização e melhorando a acessibilidade do software. Apenas os menus Arquivo e Ajuda ficam habilitados a princípio. O menu Execução é habilitado quando algum arquivo válido for aberto. Os outros menus restantes, Ordenação e Rótulos, são habilitados quando alguma árvore de entropia é criada. 
O menu Arquivo é utilizado pelo usuário quando este quer escolher o arquivo que será analisado ou quando quer gravar o conteúdo da grade de dados para um arquivo. O arquivo de entrada deve seguir o modelo descrito na seção 4.4. A gravação, gera um arquivo no mesmo formato do arquivo de entrada. Com isso, uma discretização que tenha sido feita pode ser gravada evitando ter que ser refeita em análise futura.

O menu Execução contém as opções mais importantes do software, é lá que estão as opções de cálculo de entropia e discretização e ainda tem a opção de olhar os histogramas dos dados presentes na grade de dados. Esse menu fica com todos seus itens desabilitados (não acessíveis) enquanto não houver um arquivo válido aberto.

Os menus Ordenação e Rótulos, cuidam da apresentação da árvore de entropia. Ordenação serve para o usuário escolher por qual critério EntropCalc irá ordenar os nós da árvore de entropia. Dentre os valores, temos Label que é o nome da combinação usada (ex: var1, var2, var3), $H 1$ é a entropia condicional que segue $H(Z|Y| X), H 2$ é a entropia condicional que segue $H(Z \mid X, Y), H X S$ é a entropia simétrica $H(X, Y, Z)$ e QI é a Quantidade de Informação. A única particularidade aqui é que a ordenação por quantidade de informação é decrescente, ao contrário das outras, já que quanto maior o a quantidade de informação, melhor o experimento realizado, no caso, melhor foi o resultado da adição da última variável ao conjunto testado.

O menu de Rótulos segue a mesma nomenclatura do menu de ordenação e só serve para limpar um pouco a tela, eliminando resultados que o usuário pode não querer ver. A princípio somente $H 1$ é mostrado, os outros resultados irão aparecendo à medida que forem selecionados no menu.

O menu de Ajuda só mostra uma caixa diálogo informações sobre o software, como o nome de quem o escreveu e qual o objetivo.

\subsubsection{Tela de Opções de Cálculo de Entropia}

Nesta caixa de diálogo o usuário poderá escolher as opções necessárias para o cálculo de entropia. Dentre as opções possíveis está a quantidade de variáveis que entram no cálculo ("Número de Variáveis"). Este número indica o tamanho do conjunto que será considerado no cálculo. Por exemplo, caso o usuário escolha dois, implicará em cálculos com juntos de duas variáveis do tipo $H(\mathrm{X} \mid \mathrm{Y})$ e $H\left(X, Y^{\circ}\right)$, caso seja très, haverá o cálculo de $H\left(X\left|Y^{\prime}\right| Z\right), H(X \mid Y, Z)$ e $H(X, Y, Z)$ e assim por diante. O número de variáveis, em 


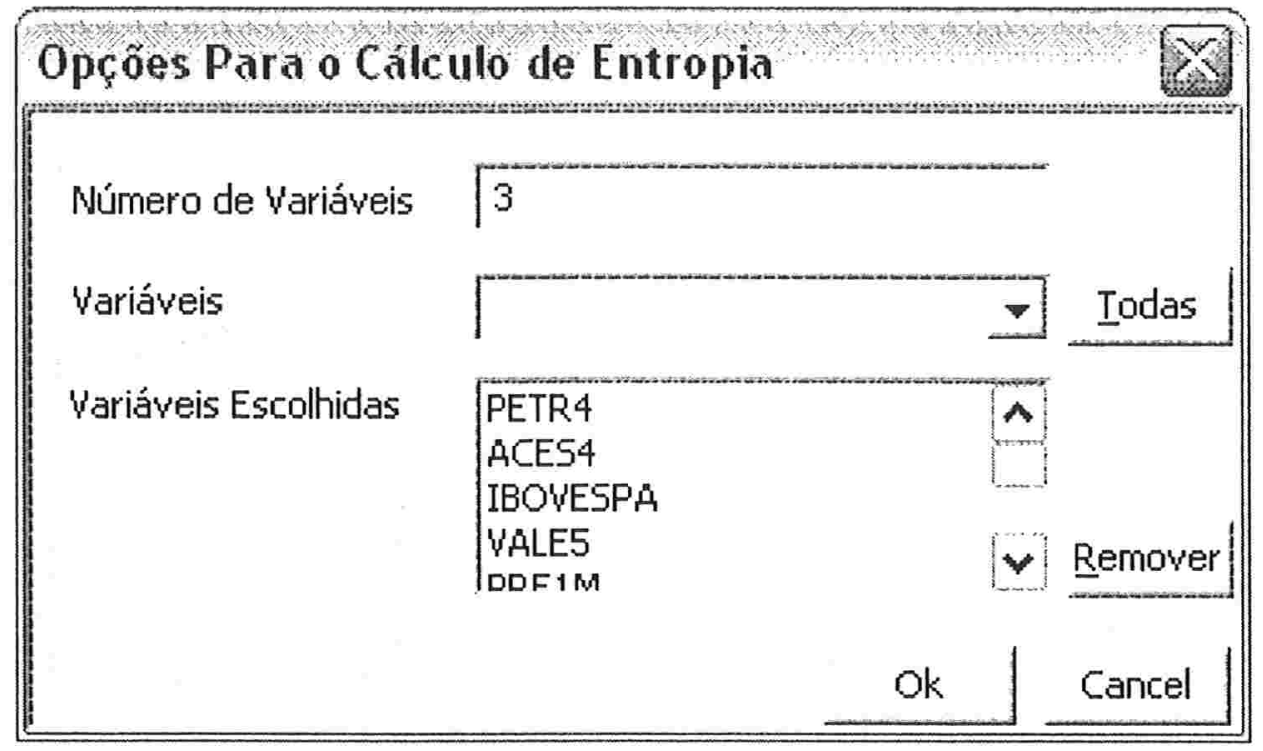

Figura 2: Tela de opções do cálculo de entropia

outras palavras, indica as combinações que serão geradas a partir das variáveis escolhidas (2 a 2, 3 a 3). Estas combinações são sem repetição, logo a entropia do conjunto com três variáveis $(\mathrm{a}, \mathrm{a}, \mathrm{b})$, por exemplo, não será calculada.

Na caixa de seleção exclusiva (Combo Box) "Variáveis" o usuário escolhe quais das variáveis possíveis devem participar do teste. Cada uma escolhida, é então retirada do controle em questão e colocada na lista abaixo. Se nenhuma for escolhida, por padrão, serão usadas todas, isso é feito para facilitar e deixar a utilização desse diálogo mais simplificada. O botão "Todas" que move todas as variáveis existentes no Combo Box para a lista de variáveis escolhidas.

O botão "Remover" retira a variável que esteja selecionada na lista, devolvendo-a para o Combo Box.

O valor do campo "Número de Variáveis" deve ser menor ou igual ao número de variáveis presentes na lista "Variáveis Escolhidas", caso contrário, ao se clicar no botão OK, o diálogo dará uma mensagem de erro e não deixará prosseguir até que o usuário modifique o valor.

\subsubsection{Tela de Opções de Discretização}

A caixa de diálogo "Discretização" controla quais variáveis serão discretizadas e por qual método de discretização. 


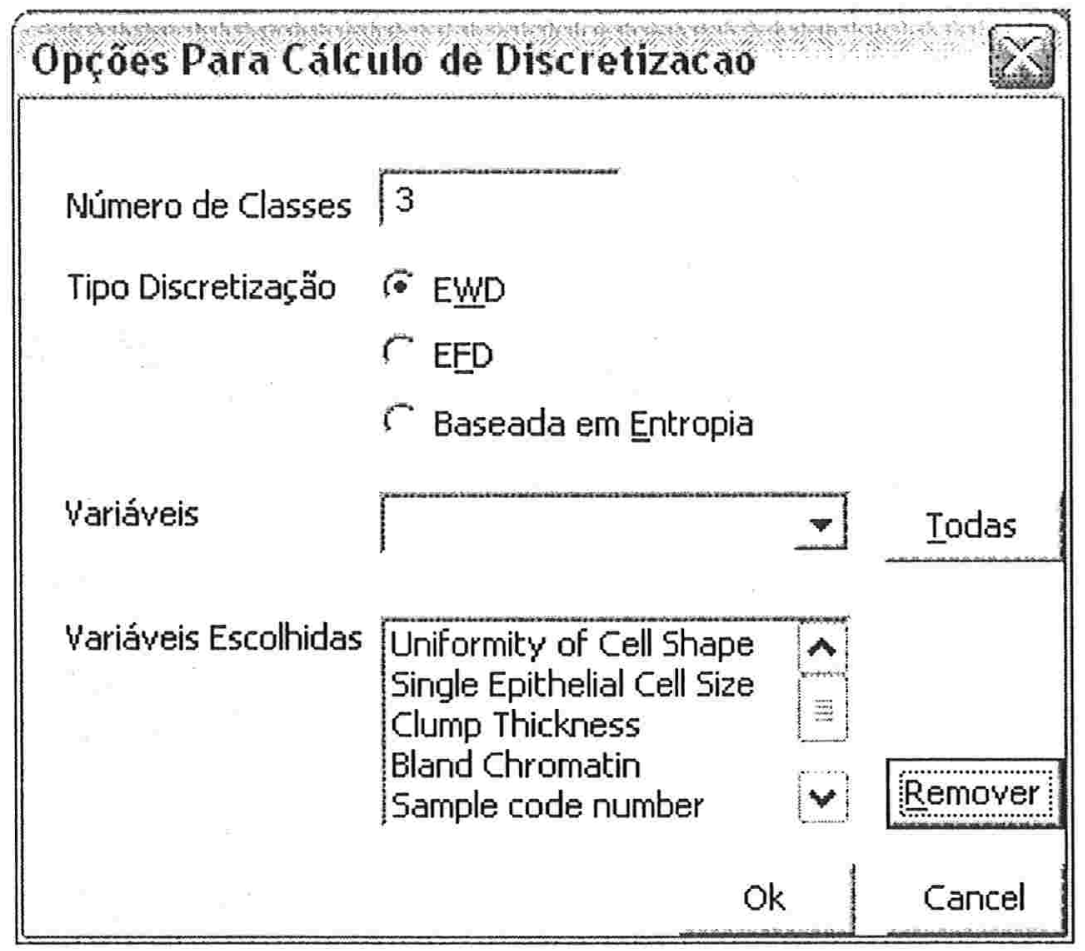

Figura 3: Tela de escolha das opções de Discretização

O primeiro campo é o "Número de Classes" que para a discretização $E W D$ e $E F D$ é o número $k$ de sub-conjuntos em que se irá separar os valores durante a discretização. No caso da discretização baseada em entropia esse valor é ignorado. Se o usuário não escolher nenhum valor e mesmo assim escolher o método $E W D$ ou $E F D$, a discretização usará o valor padrão de $\sqrt{n}$ classes (bins).

Na seqüência o usuário tem um botão de escolha exclusiva ( Radio Button ) com as opções de discretização que podem ser feitas.

Abaixo vêm o mesmo modelo de escolha de variáveis da caixa de diálogo de opções do cálculo de entropia.

Caso a discretização baseada em entropia seja escolhida, o programa irá ainda pedir para o usuário escolher uma variável de suporte.

\subsubsection{Tela Histogramas}

Para visualização de seus dados, o usuário ainda pode utilizar a ferramenta de visualização de histogramas disponibilizada pelo menu "Execução".

O seu uso é muito simples. Ao ser invocado haverá um histograna e um Combo Box, 


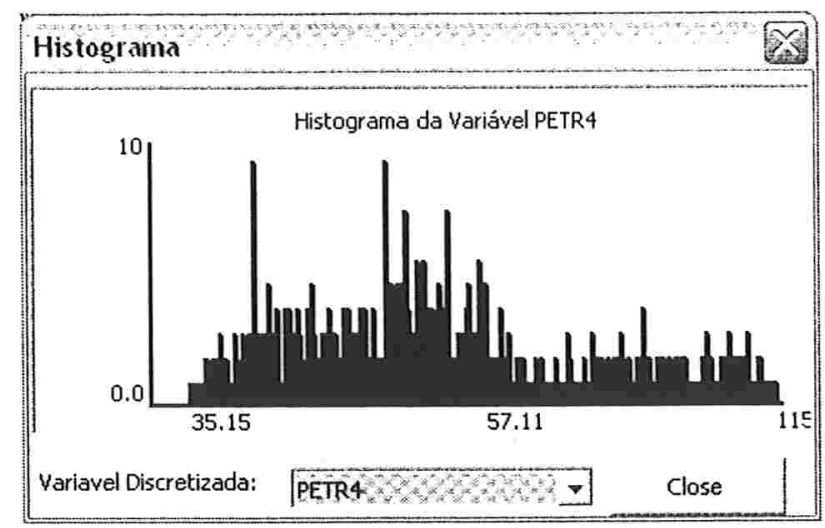

Figura 4: Tela de Histograma 1

neste controle o usuário poderá escolher qual histograma quer ver. Ex:

\subsubsection{Tela Principal}

A tela principal é dividida em duas partes, uma parte contém a árvore com os resultados do cálculo de entropia e a outra parte contém uma tabela com os dados do arquivo de entrada.

A árvore de entropia tem como nó raiz o nome do arquivo de entrada, precedido de um rótulo que é o número da execução, facilitando assim a distinção entre vários testes seguidos. Os nós seguintes na hierarquia são das combinações de variáveis que foram testadas, por exemplo (va1, var2), (var1, var3), etc. Os níveis seguintes são os valores possíveis de cada variável seguindo a hierarquia. Exemplo

\begin{tabular}{|c|c|}
\hline var1 & var2 \\
\hline 1 & 4 \\
1 & 1 \\
5 & 8 \\
5 & 1 \\
1 & 6 \\
5 & 6 \\
1 & 6 \\
\hline
\end{tabular}

Essa entrada de dados, no cálculo de entropia utilizando as duas variáveis, geraria a árvore mostrada na figura 5 . 


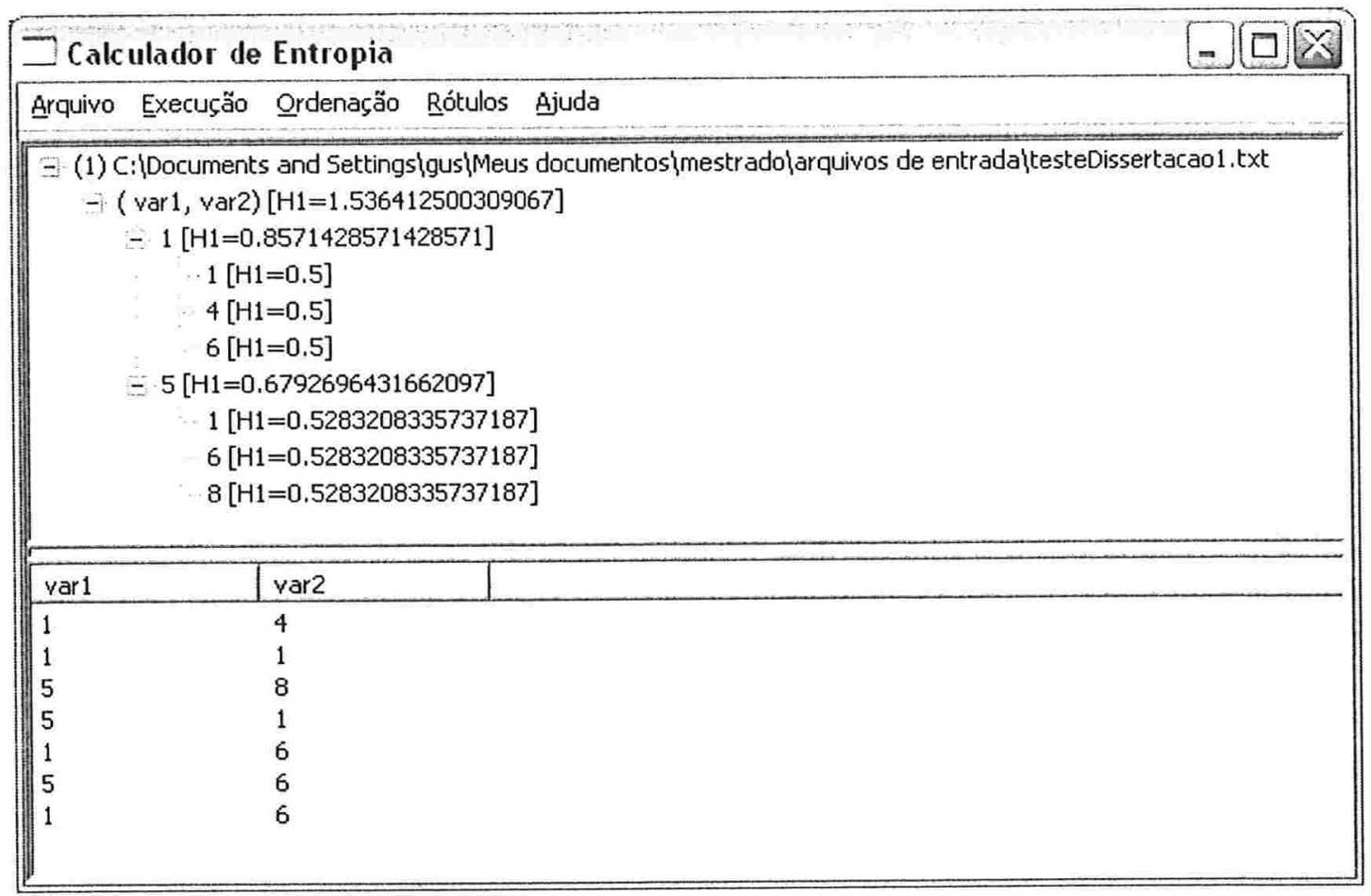

Figura 5: Árvore de Entropia

\subsection{Arquivo de Entrada}

O formato do arquivo de entrada consiste de linhas com valores separados por ";".

A primeira linha contém os nomes das variáveis que serão estudadas, as demais linhas são os dados relacionados a cada variável. Exemplo:

$$
\begin{aligned}
& \mathrm{x} 0 ; \mathrm{x} 1 ; \mathrm{x} 2 ; \mathrm{x} 3 \\
& \text { 1 } \\
& 0 \\
& 2 ; 1 ; 2 \\
& 4 ; 0 \\
& 2 ; 4 ; 0 \\
& 2 ; 0 ; 3 \\
& 4 ; 3 ; 3 \\
& 0 ; 2 ; 1 \\
& 1 ; 3 ; 3 ; \\
& 3 ; 0 ; 4
\end{aligned}
$$

Nesse exemplo temos uma entrada com quatro variáveis $x 0, x 1, x 2, x 3$ e para cada 
variável 10 valores.

A ordem que os valores aparecem em cada coluna é fator importante para os cálculos que irão ser feitos. No exemplo acima, se fôssemos fazer a mesma análise que é feita no software, para as probabilidades, teríamos que $P(x 1=4)=1 / 5=0,2, P(x 1=4 \mid x 0=$ $5)=1$ e $P(x 1=2 \mid x 0=0)=0,5$. Logo ao se procurar por relações entre as variáveis sendo analisadas, cada linha será analisada como uma tupla de dados.

\subsection{Arquivo de Resultados de Saída}

A cada vez que é requisitado o cálculo de entropia, um arquivo "html" e um arquivo "cvs" com os resultados são escritos no mesmo diretório do arquivo de entrada - Os arquivo tem como padrão o nome do arquivo de entrada, acrescido do prefixo "saida_" e um sufixo que diz o número de variáveis utilizadas por combinação no cálculo e por fim a extensão específica. Por exemplo, se o arquivo de entrada for o "dadosEntrada.txt" e em cima de seus dados for feito um cálculo combinando as variáveis 3 a 3 (número de variáveis escolhida do diálogo de opções de entropia foi três) então os arquivos de saída serão "saida_dadosEntrada.txt_[Vars_3].html" e "saida_dadosEntrada.txt_[Vars_3].cvs".

No arquivo "html" estão presentes todos os resultados separados por seção de acordo com $H(X|Y| Z), H(X \mid Y, Z), H(X, Y, Z)$ e quantidade de informação. Cada seção está ordenada, sendo que a quantidade de informação esta em ordem decrescente e as outras três seções em ordem crescente, seguindo a mesma idéia explicada em 4.3.1.

No arquivo "cvs" cada linha consiste em um código, a tupla e o valor calculado para esta tupla, separados por ";". Os códigos podem ser $0,1,2$ ou 3 e significam:

$$
0=H(X|Y| Z) .1=H(X \mid Y, Z) .2=H(X, Y, Z) .3=\text { Quantidade de Informação. }
$$

Logo, se no arquivo "cvs" tivermos a linha $0 ;(\mathrm{a}, \mathrm{b}, \mathrm{c}) ; 0.3$ significa que a tupla a, b e c tem uma entropia condicional igual a 0.3. Com este tipo de arquivo fica mais fácil utilizar os resultados obtidos com o Entrop Calc como entrada para outro software de análise. 


\subsection{Executando o Software}

Para executar o software Entrop Calc é necessário que o sistema já tenha suporte a Java versão 1.4 pelo menos, e tenha os seguintes "jar's" presentes no mesmo diretório que está o "jar" da aplicação: swt.jar, jface.jar, jfacetext.jar, runtime.jar, osgi.jar. Para o sistema operacional Windows, ainda é necessário que esteja no caminho de execução, ou no mesmo diretório da aplicação, a biblioteca dinâmica swt-win32-3063.dll(para execução no Windows, outros sistemas precisam da biblioteca pertinente, no Linux, por exemplo, é a libswt-gtk-3063.so. A linha de comando para a execução do software será então:

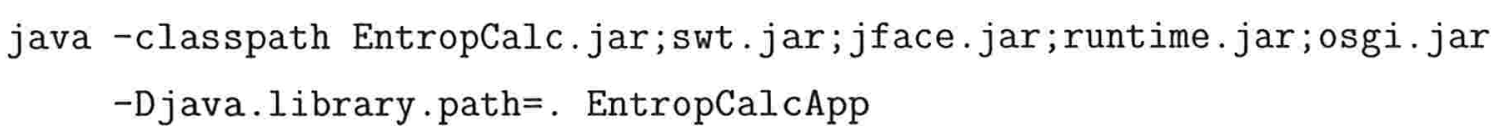

Dois parâmetros comums, do Java, na utilização do Entrop Calc são -Xmx512m e -Xms72m que quando utilizados aumentam o tamanho da memória disponível para o Java. Estes parâmetros são necessário quando o usuário precisa testar combinações com muitas variáveis, ocupando assim muita memória.

Existem um conjunto de parâmetros do próprio Entrop Calc que podem ser usados para facilitar a utilização do software e permitindo assim automatizar tarefas repetitivas, como por exemplo analisar um mesmo arquivo diversas vezes, podemos usar o parâmetro "-f" e o nome do arquivo; isto fará com que o software já inicie com este arquivo aberto, pronto para ser analisado.

O conjunto completo com todos os parâmetros:

-help ou -? - mostra a listagem de parâmetros possíveis.

-nodialog - faz com que o diálogo nao seja mostrado.

-f "nome de arquivo entrada" - diz qual arquivo deve ser aberto ao iniciar o software.

-g "nome de arquivo saida" - grava o conteúdo da grade no arquivo passado como parâmetro na sequência.

-cvars "var1;var2;var3" - diz quais os indices das variaveis que serão usadas no cálculo de entropia. Essa lista deve estar entre aspas e separada por $\because ;$ por exemplo $\ddot{1} ; 3 ; 5$ : 
-cnumvars <número de variáveis > - diz quantas variáveis serão usadas, no cálculo de entropia, por vez".

-dmetodo <número do método > - diz qual tipo de discretização será usada (0 = EWD, 1 = EFD, 2 = Baseada em Entropia).

-dvars "var1;var2;var3" - diz quais os índices das variáveis que serão discretizadas.

-dbins < número de bins> - diz quantos bins serão usados na discretização.

-dsuporte <índice variável de suporte> - diz qual o índice da variável servirá de suporte para discretização, só útil para o método 2 (Baseado em Entropia). 


\section{Tutorial}

A utilização do Entrop Calcpara se encontrar padrões, dada a explicação da teoria e das funcionalidades do software fica bem simples. Nesta seção iremos chegar a uma metodologia simples de análise usando o Entrop Calc.

Neste tutorial iremos analisar as seguintes series:

$$
\begin{aligned}
& 1,2,3,4,5,6,7,8,9,10 \\
& 2,4,6,8,10,12,14,16,18,20 \\
& 1,2,1,2,1,2,1,2,1,2 \\
& 2,2,2,2,2,2,2,2,2,2
\end{aligned}
$$

O primeiro passo será montar o arquivo de entrada. Para tanto, iremos denominar cada série por uma letra e com isso montar o arquivo usando o padrão definido na seção 4.4. Obtemos então o resultado:

$$
\begin{aligned}
& \mathrm{a} ; \mathrm{b} ; \mathrm{c} ; \mathrm{d} \\
& 1 ; 2 ; 1 ; 2 \\
& 2 ; 4 ; 2 ; 2 \\
& 3 ; 6 ; 1 ; 2 \\
& 4 ; 8 ; 2 ; 2 \\
& 5 ; 10 ; 1 ; 2 \\
& 6 ; 12 ; 2 ; 2 \\
& 7 ; 14 ; 1 ; 2 \\
& 8 ; 16 ; 2 ; 2 \\
& 9 ; 18 ; 1 ; 2 \\
& 10 ; 20 ; 2 ; 2
\end{aligned}
$$

Com o arquivo de entrada montado, vamos usá-lo no Entrop Calce verificar qual a entropia de cada série. 
Utilizando o diálogo de configuração do cálculo de entropia (seção 4.3.2), escolhemos todas as séries e como número de variáveis escolhemos apenas uma, ou seja, apenas a entropia de uma série por vez.

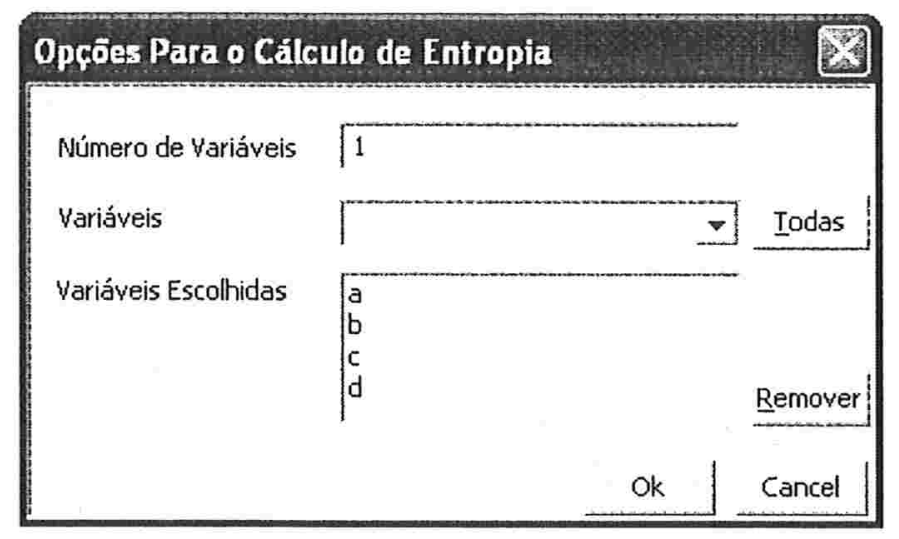

Figura 6: Configuração inicial do Tutorial

Com isso obtivemos os seguintes resultados:

$$
\begin{aligned}
& (\mathrm{d}) \rightarrow 0.0 \\
& (\mathrm{c}) \rightarrow 1.0 \\
& (\mathrm{a}) \rightarrow 3.321928094887362 \\
& (\mathrm{~b}) \rightarrow 3.321928094887362
\end{aligned}
$$

A série $d$ tem entropia 0 , isto se deve ao fato de todos os elementos contidos nela terem o mesmo valor, ou seja, $P(x)=1$ quado $x=2$ e isto, como visto em 5 leva a uma entropia 0.

As séries $a$ e $b$ tiveram o mesmo valor de entropia. Este, pelo próprio Entrop Calc, é o valor máximo para uma série com 10 elementos. Como visto da propriedade 7 , isto só acontece quando todos os elementos da série são diferentes, e isto é o que ocorre nas duas séries.

Agora que já analisamos individualmente cada série, iremos analisar combinações delas duas a duas e com isso tentar achar alguma relação entre elas.

Utilizando o diálogo de cálculo de entropia (4.3.2) escolhemos todas as variáveis mas agora o número de variáveis passará a ser 2.

Obtemos então o seguinte resultado: 


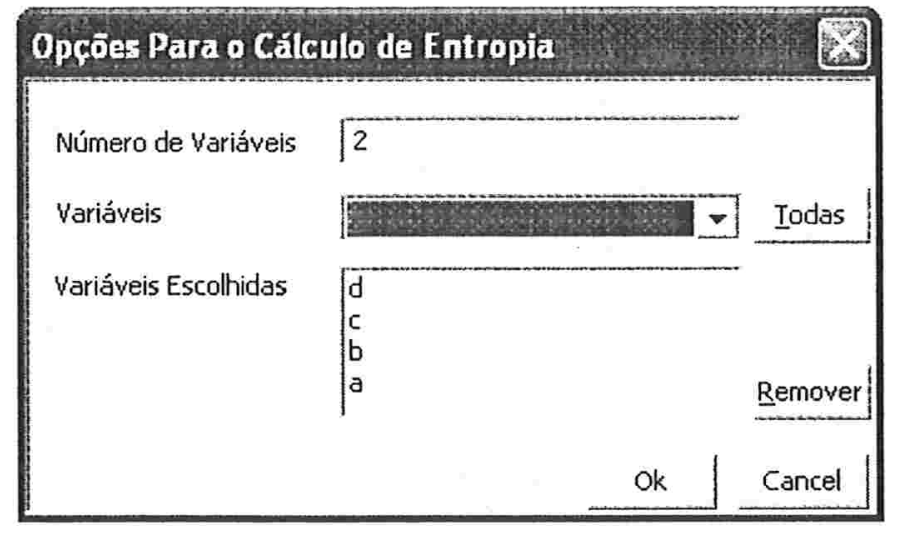

Figura 7: Configuração de cálculo com 2 variáveis

$$
\begin{aligned}
& (\mathrm{b}, \mathrm{a}) \rightarrow 0.0 \\
& (\mathrm{~d}, \mathrm{c}) \rightarrow 1.0 \\
& (\mathrm{c}, \mathrm{b}) \rightarrow 2.321928094887362 \\
& (\mathrm{c}, \mathrm{a}) \rightarrow 2.321928094887362 \\
& (\mathrm{~d}, \mathrm{~b}) \rightarrow 3.321928094887362 \\
& (\mathrm{~d}, \mathrm{a}) \rightarrow 3.321928094887362
\end{aligned}
$$

Podemos ver que $H(a \mid b)=0.0$, o que é muito interessante. Quando analisamos cada variável separadamente, estas duas obtiveram as maiores entropias e agora quando analisadas em conjunto obtiveram a menor. Para entendermos o que aconteceu basta olharmos a série $a$ e a série $b$. A série $b$ é a série $a$ mas com cada elemento multiplicado por 2, logo, se soubermos um valor de uma das séries, dado o que conhecemos delas, podemos deduzir o valor correspondente na outra série, e é esse tipo de conhecimento que queremos conseguir quando fazemos analises utilizando entropia, ou seja, conseguir uma previsibilidade dado um conhecimento a priori. 


\section{Experimentos}

Os experimentos foram direcionados em dois sentidos. O primeiro testar a ferramenta e suas funcionalidades para verificar se realmente seu uso contribui de alguma forma para o pesquisador na busca por correlações escondidas. O segundo tipo foi entregar o Entrop Calc para um usuário leigo de computação, mas que tenha conhecimento de uma área específica, e pedir para que tentasse utilizar o software para fazer algumas análises e com isso verificar se o software realmente é de fácil utilização.

\subsection{Primeira Série de Experimentos}

A primeira etapa de testes da aplicação verificou se o mecanismo de análise está funcional e coerente.

O primeiro arquivo de teste consiste em dados referentes a câncer de mama coletados pela Universidade de Winsconsin. Este arquivo contém 699 linhas e está presente no sítio UCI(26) que é um repositório de dados experimentais para uso em algoritmos de aprendizado computacional.

Foram utilizados nos testes dois computadores: um Semptron 2200, 512 MB de memória e um Pentium $42.66 \mathrm{GHz}, 512 \mathrm{MB}$ de memória. Ambos usam o sistema operacional Windows XP.

\subsubsection{Resultados}

Neste primeiro teste o arquivo analisado é a versão oficial sem nenhuma alteração, utilizando apenas uma variável para verificar quais as condições da distribuição. 


\begin{tabular}{|ll|}
\hline ( Class) & $\rightarrow 0.9293179372497983$ \\
( Mitoses) & $\rightarrow 1.1103327219639885$ \\
( Normal Nucleoli) & $\rightarrow 2.046418606889183$ \\
( Mare Nuclei) & $\rightarrow 2.1042548101678085$ \\
( Single Epithelial Cell Size) & $\rightarrow 2.286494120644736$ \\
( Uniformity of Cell Size) & $\rightarrow 2.3358761395723104$ \\
( Uniformity of Cell Shape) & $\rightarrow 2.494163805803505$ \\
( Bland Chromatin) & $\rightarrow 2.7661582667444415$ \\
( Clump Thickness) & $\rightarrow 3.0437692332778825$ \\
( Sample code number) & $\rightarrow 9.280515880023742$ \\
\hline
\end{tabular}

Nessa primeira análise verificamos que a variável "Sample code number" não contém quase estrutura nenhuma pois tem um valor de entropia próximo de $\log _{2}(699)=9.449148$. Esse resultado era esperado já que é apenas o índice da tupla. Com isso já podemos retirar da análise esta variável já que não irá acrescentar em nada.

\subsubsection{Resultados com Combinação de Mais Variáveis}

No próximo teste iremos aumentar o número de variáveis analisadas por conjunto para 2. Não será usada a variável "Sample code number" seguindo o resultado do teste anterior.

\begin{tabular}{|lc|}
\hline ( Uniformity of Cell Size, Class) & $\rightarrow 0.24504931506908784$ \\
( Uniformity of Cell Shape, Class) & $\rightarrow 0.26834529344436203$ \\
( Bare Nuclei, Class) & $\rightarrow 0.3357755776380628$ \\
( Bland Chromatin, Class) & $\rightarrow 0.3815539256207105$ \\
( Single Epithelial Cell Size, Class) & $\rightarrow 0.4152266498144925$ \\
( Normal Nucleoli, Class) & $\rightarrow 0.4538449041729523$ \\
( Clump Thickness, Class) & $\rightarrow 0.46458963460435904$ \\
( Marginal Adhesion, Class) & $\rightarrow 0.48030261229127313$ \\
( Mitoses, Class) & $\rightarrow 0.7191937344913691$ \\
( Single Epithelial Cell Size, Mitoses) $\rightarrow 0.8209707931634238$ \\
\hline
\end{tabular}

Podemos perceber nesse teste que a variável "Class" está muito correlacionada a todas as outras já que todas suas combinações com as outras variáveis tem uma entropia 
muito baixa.

Analisando, dentro desse mesmo teste, os valores da entropia simétrica $(H(X, Y, Z))$ :

\begin{tabular}{|lc|}
\hline ( Mitoses, Class) & $\rightarrow 1.829526456455357$ \\
( Bare Nuclei, Class) & $\rightarrow 2.4400303878058716$ \\
( Uniformity of Cell Size, Class) & $\rightarrow 2.5002635110621347$ \\
( Marginal Adhesion, Class) & $\rightarrow 2.6759992456955835$ \\
( Single Epithelial Cell Size, Class) & $\rightarrow 2.701720770459228$ \\
( Uniformity of Cell Shape, Class) & $\rightarrow 2.762509099247866$ \\
( Normal Nucleoli, Mitoses) & $\rightarrow 2.895467763500796$ \\
( Bare Nuclei, Mitoses) & $\rightarrow 2.9792437868556267$ \\
( Marginal Adhesion, Mitoses) & $\rightarrow 3.0800863202704463$ \\
( Single Epithelial Cell Size, Mitoses) & $\rightarrow 3.107464913808159$ \\
( Bland Chromatin, Class) & $\rightarrow 3.1477121923651525$ \\
( Uniformity of Cell Size, Mitoses) & $\rightarrow 3.1642859357076922$ \\
( Uniformity of Cell Shape, Mitoses) & $\rightarrow 3.344373672721075$ \\
( Clump Thickness, Class) & $\rightarrow 3.508358867882242$ \\
\hline
\end{tabular}

Neste resultado percebemos que realmente a variável "Class" está bem relacionada a todas as outras variáveis.

\subsubsection{Resultados com Coluna Aleatória Adicional}

Para essa etapa será adicionada uma coluna com nome "Variavel Adicional" contendo valores aleatórios e também será aumentado para 3 o tamanho das combinações testadas. 


\begin{tabular}{|ll|}
\hline (Uniformity of Cell Size, Bare Nuclei, Class) & $\rightarrow 0.0883232522615$ \\
(Uniformity of Cell Shape, Bare Nuclei, Class) & $\rightarrow 0.0902788594003$ \\
(Clump Thickness, Uniformity of Cell Size, Class) & $\rightarrow 0.1278218230898$ \\
(Bare Nuclei, Normal Nucleoli, Class) & $\rightarrow 0.1321147221918$ \\
(Single Epithelial Cell Size, Bare Nuclei, Class) & $\rightarrow 0.132745871829$ \\
(Clump Thickness, Bare Nuclei, Class) & $\rightarrow 0.1343117278309$ \\
(Uniformity of Cell Size, Normal Nucleoli, Class) & $\rightarrow 0.1373370024059$ \\
(Clump Thickness, Uniformity of Cell Shape, Class) & $\rightarrow 0.1374535106955$ \\
(Uniformity of Cell Shape, Bland Chromatin, Class) & $\rightarrow 0.1399859825784$ \\
(Uniformity of Cell Shape, Normal Nucleoli, Class) & $\rightarrow 0.1449739328882$ \\
(Uniformity of Cell Size, Bland Chromatin, Class) & $\rightarrow 0.1478325214480$ \\
\hline ‥ & $\rightarrow \cdots$ \\
\hline (Single Epithelial Cell Size, Bare Nuclei, Bland Chromatin) & $\rightarrow 1.74369192760$ \\
(Marginal Adhesion, Single Epithelial Cell Size, Bland Chromatin) $\rightarrow 1.762614740711$ \\
(Clump Thickness, Bland Chromatin, Variavel Aleatoria) & $\rightarrow 4.02929204151$ \\
(Clump Thickness, Uniformity of Cell Shape, Variavel Aleatoria) & $\rightarrow 4.435726058576$ \\
(Clump Thickness, Single Epithelial Cell Size, Variavel Aleatoria) & $\rightarrow 4.51340953099$ \\
(Clump Thickness, Marginal Adhesion, Variavel Aleatoria) & $\rightarrow 4.5326961875$ \\
(Clump Thickness, Uniformity of Cell Size, Variavel Aleatoria) & $\rightarrow 4.5927269366$ \\
(Clump Thickness, Bare Nuclei, Variavel Aleatoria) & $\rightarrow 4.71983597183$ \\
\hline
\end{tabular}

Com esses resultados fica mais evidente ainda a relação da variável "Class" com as outras. Outro detalhe interessante é que a variável "Variavel Adicional", em sua primeira aparição na lista ordenada por entropia, se varifica um salto nos valores, pulando de 1.76261 para 4.02929, mostrando que ela realmente não colabora com o cálculo, tal como era o esperado nessa análise ja que seus valores são aleatórios e a entropia somente dela é igual a $9.449148645=\log _{2}(699)$ que é a entropia máxima para esse tamanho de amostra.

\subsubsection{Conclusão da Primeira Etapa}

Com os resultados obtidos, pode-se concluir que, a variável "Class" é altamente influenciada por todas as outras. A inclusão da variável com valores aleatórios não atrapalhou a análise, mostrando que a aplicação consegue ajudar a separar dados pertinentes de ruído. O mecanismo de análise ficou simples de ser usado, e com a ajuda das manipulações da árvore de resultados, ordenação e inclusão ou remoģão de rótulos, fica ainda 
mais fácil ver o os melhores e os piores resultados podendo assim chegar a novas hipóteses para estudo.

Esse resultado era o esperado já que a variável "Class" representa a presença de câncer de mama ou não e as outras colunas, menos a de índice, são algumas das características apresentadas por uma pessoa com a doença.

Outra conclusão que podemos chegar, é que, com a metodologia utilizada, pode-se ir filtrando quais variáveis devem continuar nas análises e quais são apenas ruído, facilitando assim a obtenção de resultados e diminuindo a quantidade de dados necessária que devem ser verificados.

\subsection{Segunda Série de Experimentos}

Esta segunda etapa de testes utilizou um arquivo com séries históricas. O arquivo contém preços de fechamento de 20 ativos do mercado financeiro que ocorreram entre os dias 04/01/2000 e o dia 29/04/2005 (1175 tuplas).

A variável "data" é o dia em que esse fechamento ocorreu. Não faz sentido colocar este campo na análise já que foi incluido no conjunto de dados apenas para suporte.

\subsubsection{Resultados Simples(1 Variável por Combinação)}

Resultado do cálculo de entropia com combinação de apenas uma variável, entropia simples. 


\begin{tabular}{ll|}
\hline ( CHAP3 Equity) & $\rightarrow 5.143093595617538$ \\
( CLSC6 BS Equity) & $\rightarrow 5.8779507932266695$ \\
( UBBR4 Equity) & $\rightarrow 7.273494669361969$ \\
( INEP4 BS Equity) & $\rightarrow 7.500457049787857$ \\
( ACES4 Equity) & $\rightarrow 7.572731069370371$ \\
( OZBG Comdty) & $\rightarrow 8.236424150132878$ \\
( TSPP3 Equity) & $\rightarrow 8.53706744272203$ \\
( FFTL4 Equity) & $\rightarrow 8.623509819374645$ \\
( ITAU4 BS Equity) & $\rightarrow 9.092196036743122$ \\
( EMBR4 Equity) & $\rightarrow 9.176838765394388$ \\
( BBDC4 Equity) & $\rightarrow 9.184808511032477$ \\
( VALE5 BS Equity) & $\rightarrow 9.272031351652187$ \\
( PETR4 BZ Equity) & $\rightarrow 9.304715154536233$ \\
( SBSP3 Equity) & $\rightarrow 9.375401715364587$ \\
( TNLP4 Equity) & $\rightarrow 9.420756377185851$ \\
( CGAS5 Equity) & $\rightarrow 9.514793123457343$ \\
( BRL Curncy) & $\rightarrow 9.750427115856136$ \\
( NKY Index) & $\rightarrow 10.082892328677337$ \\
( INDU Index) & $\rightarrow 10.128347570834132$ \\
( IBOV Index) & $\rightarrow 10.198445041452537$ \\
\hline
\end{tabular}

Para o número de linhas desse arquivo, o valor máximo de entropia é 10.1984450414. Podemos notar que os valores de entropia obtidos não estão muito baixos, e na maioria, estão muito próximos do valor máximo. Isso se deve ao fato que dificilmente um valor de fechamento se repete muitos dias no mercado financeiro, e as vezes a diferença é em centavos, mas o cálculo não leva isso em consideração, se o valor for diferente mesmo que por apenas um centavo, é considerado outro elemento. Esse ambiente sugere a utilização de uma discretização.

O próximo resultado mostra as entropias calculadas da mesma forma que anteriormente mas agora todos os dados foram discretizados com o EWD, utilizando um número de classes igual a $35(\approx \sqrt{1175})$. Com esses parâmetros obtivemos o seguinte resultado: 


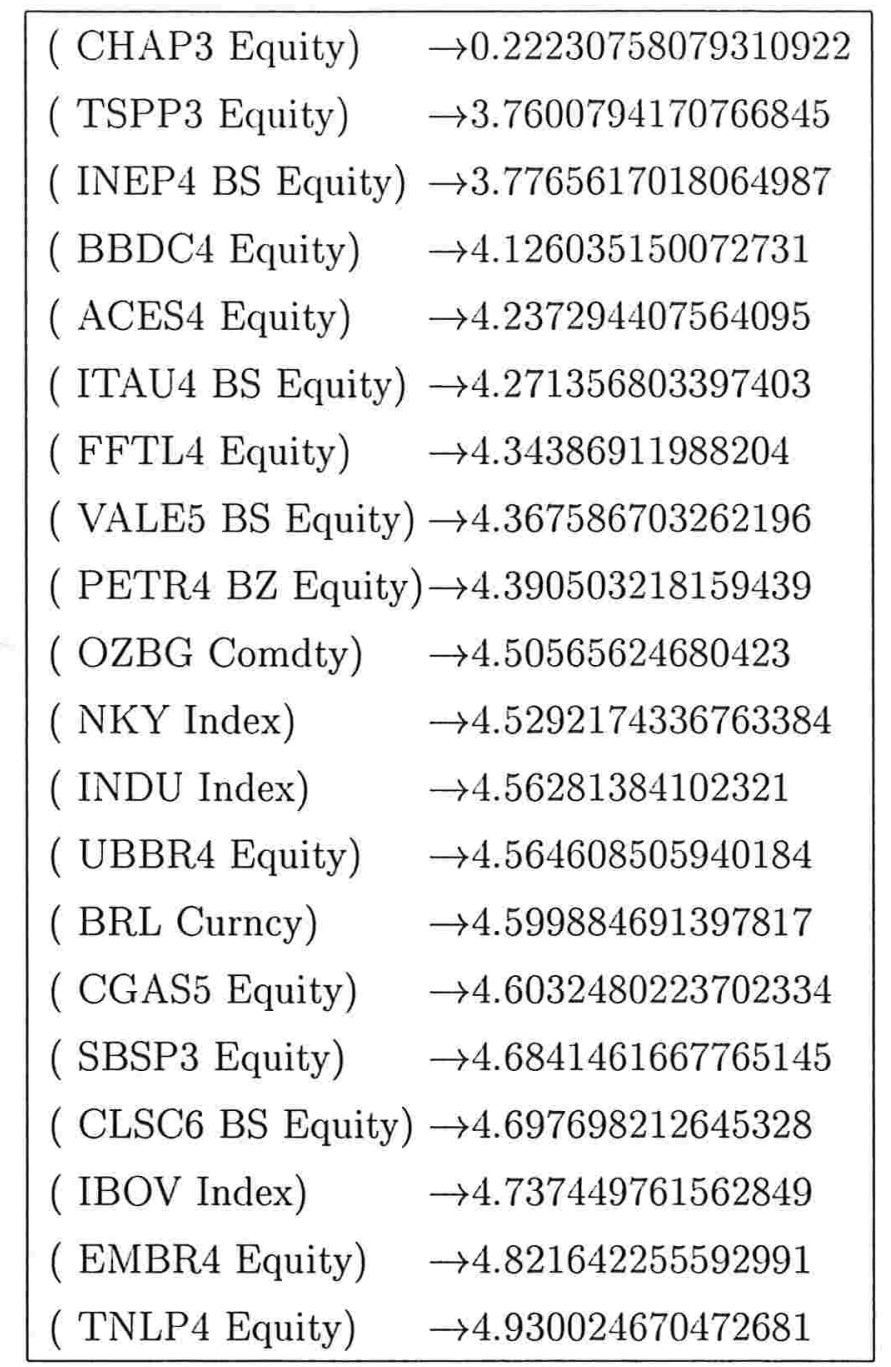

Podemos perceber que houve uma melhora para a análise. Outro detalhe que vale a pena ser notado é que a variável "CHAP3 Equity" com a discretização acabou tendo uma distribuição bem definida como mostrado no histograma da figura 8:

Analisando melhor a série histórica da CHAP3, fica fácil entender o porquê desse resultado. Ela não tem muita variação de preços, no mercado financeiro diria-se que ela é pouco negociada logo seus valores de fechamento não ocilam muito.

Esse resultado enfatiza o fato de o usuário do programa ter que ter conhecimento razoável sobre os dados com que está trabalhando. Outro resultado importante é pode-se perceber um dos usos da discretização e o porquê dela estar presente no Entrop Calc. 


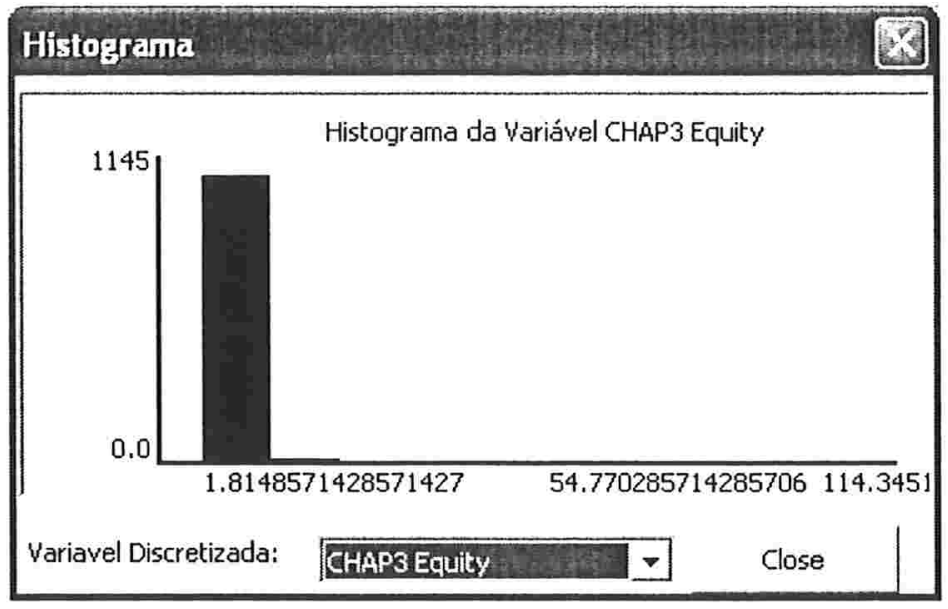

Figura 8: Histograma da variável CHAP3 Equity

\subsubsection{Resultados com Duas Variáveis}

No próximo experimento foi calculada a entropia com duas variáveis, aproveitando os conjuntos já discretizados na seção 6.2.1: 


\begin{tabular}{lll}
\hline ( NKY Index, CHAP3 Equity) & $\rightarrow 0.05948741596861379$ \\
( INEP4 BS Equity, CHAP3 Equity) & $\rightarrow 0.07269202210032295$ \\
( EMBR4 Equity, CHAP3 Equity) & $\rightarrow 0.10085137442189075$ \\
( TSPP3 Equity, CHAP3 Equity) & $\rightarrow 0.1015593097568258$ \\
( SBSP3 Equity, CHAP3 Equity) & $\rightarrow 0.11323914610029227$ \\
( INDU Index, CHAP3 Equity) & $\rightarrow 0.12148237915007147$ \\
( BRL Curncy, CHAP3 Equity) & $\rightarrow 0.1226094907602946$ \\
( OZBG Comdty, CHAP3 Equity) & $\rightarrow 0.13528847937378435$ \\
( CGAS5 Equity, CHAP3 Equity) & $\rightarrow 0.14782122251063923$ \\
( TNLP4 Equity, CHAP3 Equity) & $\rightarrow 0.14961489610974454$ \\
( ITAU4 BS Equity, CHAP3 Equity) & $\rightarrow 0.1561999535395028$ \\
( ACES4 Equity, CHAP3 Equity) & $\rightarrow 0.158483225308882$ \\
( FFTL4 Equity, CHAP3 Equity) & $\rightarrow 0.16088593216246927$ \\
( BBDC4 Equity, CHAP3 Equity) & $\rightarrow 0.1617344615782591$ \\
( UBBR4 Equity, CHAP3 Equity) & $\rightarrow 0.16636633139351317$ \\
( PETR4 BZ Equity, CHAP3 Equity) $\rightarrow 0.16678458661934306$ \\
( VALE5 BS Equity, CHAP3 Equity) $\rightarrow 0.1740295657454993$ \\
( BRL Curncy, INEP4 BS Equity) & $\rightarrow 1.826088630789443$ \\
( FFTL4 Equity, VALE5 BS Equity) & $\rightarrow 1.956334406823236$ \\
( NKY Index, TSPP3 Equity) & $\rightarrow 2.035428224552794$ \\
\hline
\end{tabular}

Podemos verificar que, todas as variáveis, nas condições $(H(C H A P 3 \mid X))$ tem entropia muito baixa. A princípio pensaríamos que CHAP3 está altamente relacionada às outras variáveis. Se lembrarmos da propriedade 11 da entropia $(H(Y \mid X) \leq H(Y))$ podemos verificar que CHAP3 só segue a propriedade, e como sua entropia individual é muito mais baixa que a das outras variáveis, quando analisada em conjunto acaba baixando a entopia condicional para um valor menor que o seu próprio (0.22230). Juntando-se isso à conclusão chegada no teste anterior, que CHAP3 é pouco negociada no mercado, podemos tirá-la dos próximos testes para evitar valores ilusórios.

Este é um exemplo claro, que mostra que um usuário, sem um conhecimento específico dos dados com que esta trabalhando, poderia chegar a conclusões erradas, invalidando assim seus resultados. 


\subsubsection{Resultados com Três Variáveis}

Nesse próximo experimento foi usado combinações com três variáveis, e não foram usadas as variáveis CHAP3 e data, pelos motivos já explicados anteriormente.

\begin{tabular}{|ll|}
\hline ( CGAS5 Equity, TNLP4 Equity, TSPP3 Equity) & $\rightarrow 0.6470715685951877$ \\
( CGAS5 Equity, TNLP4 Equity, IBOV Index) & $\rightarrow 0.7377485709762162$ \\
( CGAS5 Equity, TNLP4 Equity, INEP4 BS Equity) $\rightarrow 0.7525577685756554$ \\
( BRL Curncy, TNLP4 Equity, INEP4 BS Equity) & $\rightarrow 0.7621871126721042$ \\
( NKY Index, TNLP4 Equity, TSPP3 Equity) & $\rightarrow 0.7648150179710894$ \\
( BRL Curncy, TNLP4 Equity, TSPP3 Equity) & $\rightarrow 0.7829412772235413$ \\
( CGAS5 Equity, TNLP4 Equity, VALE5 BS Equity) $\rightarrow 0.786608878357455$ \\
( ACES4 Equity, SBSP3 Equity, INEP4 BS Equity) & $\rightarrow 0.7976232130214352$ \\
( PETR4 BZ Equity, TNLP4 Equity, IBOV Index) & $\rightarrow 0.8055628821046267$ \\
( SBSP3 Equity, EMBR4 Equity, INEP4 BS Equity) $\rightarrow 0.8278833313005596$ \\
( PETR4 BZ Equity, TNLP4 Equity, TSPP3 Equity) $\rightarrow 0.8393527523073272$ \\
( BRL Curncy, TNLP4 Equity, VALE5 BS Equity) & $\rightarrow 0.839873941214313$ \\
( TNLP4 Equity, EMBR4 Equity, IBOV Index) & $\rightarrow 0.8478001886796709$ \\
( NKY Index, PETR4 BZ Equity, TSPP3 Equity) & $\rightarrow 0.851257869029226$ \\
( CGAS5 Equity, SBSP3 Equity, INEP4 BS Equity) & $\rightarrow 0.851879285794226$ \\
( TNLP4 Equity, EMBR4 Equity, INEP4 BS Equity) $\rightarrow 0.8535858513460023$ \\
( NKY Index, CGAS5 Equity, TSPP3 Equity) & $\rightarrow 0.8538181556930695$ \\
( OZBG Comdty, TNLP4 Equity, TSPP3 Equity) & $\rightarrow 0.8562326571334625$ \\
\hline
\end{tabular}

Nesse teste foi encontrado na menor entropia uma relação interessante. CGAS5 (Comgas, empresa de distribuição de gás natural), TNLP4 (Telemar, empresa de telecomunicação) e TSPP3 (Telesp Celular, empresa de telecomunicação), não apareceram com boas entropias nos testes com menos variáveis, mas agora com três variáveis aparecem com um valor de entropia bem baixo, mostrando que pode haver alguma relação entre elas. Esta vêm a ser uma hipótese a ser melhor estudada.

No caso do segundo menor valor, CGAS5, TNLP4 e IBOV Index, apareceu uma relação já conhecida do mercado financeiro. O Índice Bovespa ("IBOV Index") é uma composição de ações ponderadas por sua liquidez (número de negócios). Neste contexto, a CGAS5 e a TNLP4 tem uma participação razoável nessa composição, logo faz muito sentido que ambas influenciem no índice Bovespa. 
O terceiro menor valor é composto por CGAS5, TNLP4 e INEP4 (Inepar, industria de contrução de infra-estrutura de redes elétricas e de transmissão de rádio e telefonia). Esta é mais uma hipótese interessante que vale a pena avaliar com mais cuidado utilizando outros métodos de análise.

O quarto menor também é uma relação interessante, BRL Curency (é o preço do dolar em Reais), TNLP4 (Telemar) e INEP4 (Inepar). A relação aqui faz muito sentido, Telemar utiliza serviços providos pela Inepar e tem dívidas em Dolar, logo o preço do dolar influi na Telemar que por sua vez influi na Inepar. Este resultado mostra bem a idéia de entropia condicional.

\subsection{Análise das Impressões do Usuário}

Uma das metas principais desse projeto era desenvolver um software que fosse de fácil utilização. Este conceito pode acabar não ficando muito claro para quem cria as interfaces e implementa todo funcionamento de um software. Toda a lógica de funcionamento do sistema está fortemente ligada à experiência de utilização de software do desenvolvedor. Esta experiência pode estar muito além da de um usuário comum, e pode faltar essa percepção ao desenvolvedor, produzindo assim um software que, a seu ver, tem utilização simples, mas para um usuário comum acaba sendo muito complicado, diminuindo assim o seu interesse ou até mesmo o impossibilitando de utilizar o software.

Para tentar evitar este problema, depois do software estar pronto, um dos testes foi instalá-lo para dois usuários comuns (Usuário A e Usuário B), com muito conhecimento específico em alguma área diferente de computação. Estes usuários tentaram usar o Entrop Calc para analisar alguns conjuntos de dados que conheciam e deram um parecer sobre a facilidade de uso do software e dos resultados obtidos.

Ambos usuários tiveram uma pequena aula sobre as funcionalidade do software, sobre o conceito de entropia, como são os arquivos de entrada e como usar os parâmetros de execução.

Após a aula, os usuários puderam experimentar com o Entrop Calc por um dia, analisando seus conjuntos e conferindo hipóteses e depois responderam as seguintes perguntas:

O software é fácil de ser utilizado? 
O software é útil para suas análises?

O software tem um bom desempenho?

O que pode ser melhorado no software?

Encontrou algum erro durante a utilização do software?

Os computadores utilizados para os testes foram Pentium 4, $1.8 \mathrm{GHz}$ e $256 \mathrm{MB}$ de memória com o sistema operacional Windows XP.

\subsubsection{Resultado das Impressões do Usuário A}

Depois do dia de uso do Entrop Calc, perguntou-se então para o usuário A suas impressões sobre a ferramenta, seguindo o questionário acima:

Facilidade na utilização - Um dos objetivos principais perseguidos durante a implementação do Entrop Calc era deixar a utilização fácil. Para o usuário A esse objetivo foi alcançado. A interface foi considera simples, direta e intuitiva. Todas as funcionalidades, ficaram simples de ser usadas e "experimetadas" favorecendo ainda mais no processo de aprendizado do uso do software. A apresentação das árvores de entropia foi um ponto que foi muito elogiado. De acordo com o usuário, ficou muito bom para comparar resultados de análises diferentes, podendo-se navegar pelos resultados atuais e os anteriores na mesma tela, ajudando assim a derivar hipóteses dos resultados.

Utilidade para sua análise - Apesar de ter pouca familiaridade com o conceito de entropia, ainda foi possível ao usuário montar alguns testes e conferir alguns resultados interessantes, mostrando que a análise por entropia é coerente.

Desempenho - não houve reclamações sobre o desempenho do software. O usuário está acostumado a utilizar diversas ferramentas de análise, como por exemplo o Excel e Matlab, e mesmo assim aprovou o desempenho do Entrop Calc.

Sugestões - o usuário sugeriu que houvesse disponível no software, de forma fácil, qual valor era considerado alto para a entropia dado o número de linhas lidas do arquivo de entrada. Essa sugestão foi prontamente implementada, criando-se uma barra acima da árvore de entropia que diz quantas linhas existem na tabela (quantas 
linhas foram lidas do arquivo) e qual o valor máximo de entropia para esse número de linhas $\left(\log _{2}(N)\right.$ onde $N$ é o número de linhas, como visto na seção 7$)$. Essa barra também tem a funcionalidade de dar dicas ao usuário sobre a utilização de outras funcionalidades do software, facilitando ainda mais sua utilização.

Erros encontrados - Durante suas análises, o usuário percebeu que a discretização EWD não estava conseguindo montar intervalos que levassem em conta apenas casas decimais. O erro foi resolvido ainda dentro do prazo de utilização do software para que o teste por parte do usuário não fosse prejudicado.

\subsubsection{Resultado das Impressões do Usuário B}

O usuário B teve impressões semelhantes às do usuário $\mathrm{A}$ :

Facilidade na utilização - O usuário B não teve problemas na utilização do software. Achou muito interessante poder acrescentar os outros indicadores (quantidade de informação ou entropia simétrica) à mesma apresentação sem a necessidade de recálculo.

Utilidade para sua análise - Este usuário montou alguns conjuntos de testes simples com o intuito de entender melhor o conceito de entropia. Depois que conseguiu entender seu funcionamento, montou um conjunto para testes parecido com o das séries históricas que foi utilizado em 6.2. Após seus testes o usuário B relatou que a ferramenta Entrop Calc realmente pode ser usada de forma útil para análises que ele venha a fazer.

Desempenho - Quanto ao desempenho o usuário encontrou problemas quando tentou analisar um conjunto com mais de vinte variáveis 5 a 5 , este teste levou muito tempo para ser concluído. Isto se deve ao fato que seriam necessários 15504 nós no primeiro nível (este é o número de combinações possíveis sem contar as permutações) causando uma lentidão na hora de criar a estrutura da árvore e alocar essa quantidade inicial de espaço.

Sugestões - Foi sugerido pelo usuário colocar o número de linhas da tabela em algum

lugar para ficar mais fácil analisar os resultados. Esta requisição já havia sido feita pelo outro usuário e também foi entregue ainda no dia de testes. Outra sugestão foi diminuir o número de rótulos que aparecem inicialmente por gallo nas árvores. 
Quando o pacote de testes foi entregue aos usuários, todos os rótulos estavam ativos inicialmente, poluindo um pouco a visão. A idéia de deixar apenas o rótulo com o nome do nó e o valor da entropia condicional habilitados já havia sido implementada mas ainda não havia um pacote com ela. No pacote com as primeiras sugestões, também foi entregue esta implementação.

Erros encontrados - Este usuário não percebeu nenhum erro.

Com esses comentários, podemos concluir que a implementação ficou como foi planejada: de fácil utilização, bom desempenho e útil para um profissional que precise analisar conjuntos de dados. 


\section{Conclusão}

O objetivo desse projeto foi criar uma aplicação que ajudasse pesquisadores, de diversas áreas, a fazer uma análise de seus dados utilizando o conceito de entropia.

A entropia foi utilizada como medida de correlação entre conjuntos e a partir desta propriedade o usuário do software pode fazer a "mineração" em seus dados e tentar achar relações escondidas que venham a ser úteis para sua pesquisa ou estudo. Foram implementados, fora o cáculo simples de entropia que é encarado como um caso particular onde as combinações são de apenas uma variável, três modos de calcular a entropia, duas assimétricas $(H(Z \mid X, Y)$ e $H(Z|Y| X))$ e uma simétrica $(H(X, Y, Z))$. A diferença está em como o Entrop Calc cálcula as freqüências e probabilidas para cada caso.

O conceito de Quantidade de Informação também foi implementado para ajudar na análise. Com essa medida, pode-se ter uma idéia melhor de qual variável agrega mais informação a um conjunto.

Ainda foram implementados três tipos de discretização para o usuário poder realizar pré-processamentos, de uma forma mais integrada, em seus conjuntos antes de tentar alguma análise. Dessa forma a ferramenta ficou mais completa, conseqüentemente mais fácil para alcançar algum resultado.

Para melhorar ainda mais a visualização dos dados, foi disponibilizado um visualisador de histogramas integrado ao EntropCalc. Com isso o usuário pode ter uma idéia melhor da situação de seu conjunto de dados.

Com todas essas ferramentas implementadas seguimos duas linhas de testes, uma com dados experimentais, testando as funcionalidades e suas utilidades de uma forma geral, já que não existia um problema específico a serem tratados, e testes com usuários para verificar se a ferramenta ficou de fácil utilização, eficiente e robusta.

Quanto aos testes com os dados experimentais chegou-se a agumas hipóteses já espe- 
radas, o que mostra que a idéia da análise utilizando-se entropia realmente funciona.

Ainda quanto aos testes com dados experimentais, foi testada a idéia de discretização para se obter resultados melhores. O resultado foi bastante satisfatório, ajudando a analisar dados de características essencialmente continuas sem muita perda de precisão e assim chegando à hipóteses já esperadas, bem como em resultados interessantes não previstos tal como visto na seção 6.2.3.

Não foram realizados testes que levassem a um número muito grande de combinações (mais que mil) pois o programa EntropCalc acaba encontrando problemas por falta de recursos computacionais. O número de cálculos é exponencial, podendo levar muitas horas para se chegar a algum resultado e o objetivo do programa não é achar resultados através de força bruta mas sim derivar hipóteses de uma forma rápida e simples de ser visualizada a partir de um conhecimento específico.

Quanto ao desempenho entre a versão protótipo em C++ e a versão final em Java, a partir de testes pudemos observar que com arquivos de 1175 linhas, calculando combinações de 10 variáveis quatro a quatro, obtivemos um resultado muito parecido, não mais do que 10 segundos em um computador com processador Athlon $1500 \mathrm{MHz}$ e 512 MB de memória ram. Isto mostra que não houve perda de desempenho significativa em relação à versão protótipo.

No caso dos testes com séries históricas de ativos do mercado financeiro, chegou-se a resultados interessantes mas simples. Para se realizar análises mais complicadas seria necessário mais conhecimento específico nessa área. Este conhecimento seria útil por exemplo na escolha de quais ativos são mais interessantes, se a série com os valores de fechamento é realmente a melhor forma de analisar o ativo, qual o melhor tamanho para uma série histórica, etc, mas esse tipo de estudo já não estaria mais o foco desse projeto.

A visualização de resultados e de dados colaborou muito para se alcançar os resultados obtidos, completando muito bem todo o ambiente de análise criado. A ferramenta que mostra os histogramas das variáveis colaborou muito para poder se entender melhor os dados sendo estudados e foi bastante utilizada durante os testes feitos, ajudando até a se entender melhor alguns resultados obtidos 6.2.1. Com esta ferramenta ficou mais simples, por exemplo, perceber quando a aplicação de uma discretização seria necessária ou se uma variável tinha pouca estrutura (pouca variação de valores).

Podemos concluir que, quanto a essa parte de testes, o objetivo foi alcançado. Todas 
as funcionalidades ficaram bem integradas e robustas. A finalidade, desse tipo de análise implementada, ficou bem clara tal como sua útilidade.

Os testes com usuários mostraram que o caminho tomado no desenvolvimento da aplicação foi satisfatório. O Entrop Calc, de acordo com os comentários dos usuários, mostrou-se muito simples de ser usado, não necessitando nenhum conhecimento específico de computação.

O único problema na utilização da aplicação, por parte dos usuários, foi compreender bem o conceito de entropia, mas depois que conseguiram compreeder a idéia de entropia e o que significa, a utilização do software ficou fácil como planejado. Esta interação com o usuário ainda serviu para melhorar a aplicação já que além de testá-la, ainda deram sugestões de como melhorar a apresentação, como visto na seção 6.3

O Entrop Calc foi eficiente tanto na obtenção quanto na apresentação dos resultados obtidos. Neste teste com usuários, verificou-se que o resultado foi como planejado. A facilidade de uso e de compreenção do software, que era um dos objetivos desse projeto, foi confirmada com as impressões dos usuários.

Além dos resultados obtidos com o software, ainda foi possível aprender a usar o arcabouço Eclipse, a API SWT, conceitos novos como entropia e quantidade de informação e até mesmo uma compreensão melhor dos termos dado e informação, do conceito de discretização e de mineração de dados.

\subsection{Trabalhos Futuros}

O Entrop Calc ainda pode ser melhorado acrescentando-se mais algoritmos de discretização. A literatura contém muitos exemplos possíveis de métodos de discretização (27) e a estrutura interna do software foi elaborada para que seja simples adicionar novas implementações de novos métodos.

Outro projeto futuro é adicionar novas formas de visualização dos dados e dos resultados, já que as formas implementadas foram muito úteis, colaborando assim mais com a compreensão dos dados por parte do usuário. 


\section{APÊEDICE A - Apêndice}

\section{A.1 Biografia de Claude Shannon}

Claude Elwood Shannon nasceu em 30 de Abril de 1916 no estado de Michigan nos Estados Unidos. Terminou sua graduação em 1936 na universidade de Michigan conseguindo os títulos de bacharel em matemática e em engenharia elétrica. Em 1940 conseguiu o título de mestre em engenharia elétrica e de doutor em matemática pelo Instituto de Tecnologia de Massachusetts (MIT). Em sua tese de mestrado, de título "A Symbolic Analysis of Relay and Switching Circuits", usava Álgebra Booleana para estabelecer uma teoria sobre a pinagem de circuitos digitais. Essa tese foi considerada a tese de mestrado mais importante e mais famosas de toda a história. Esse trabalho tem um significado muito amplo, porque circuitos digitais são fundamentais para o funcionamento dos computadores modernos para os sistemas de telecomunicação.

No ano de 1941, Shannon entrou para o departamento de matemática do Bell Labs, onde continuou afiliado até 1972. Em 1956 tornou-se professor visitante do MIT, membro permanente da faculdade em 1958 e professor emeritus em 1978.

Shannon era conhecido por seus interesses ecléticos. Uma das histórias mais populares nesse sentido, o descreve andando de monociclo enquanto fazia malabarismo com três bolinhas nos corredores do Bell Labs.

O Professor Shannon também era um ávido jogador de xadrez e uma de suas invenções foi uma máquina que conseguia jogar xadrez, máquina esta que em uma viagem à Rússia, em 1965, foi utilizada para desafiar o campeão mundial, Mikhail Botvinnik, para uma partida. Shannon perdeu a partida em 42 lances, o que foi considerado uma excelente apresentação.

Dentre suas invençōes estranhas ainda têm um rato mecânico, o qual chamava de Theseus, que conseguia achar a saída de labirintos. Esse pode ser considerado um dos 
primeiros experimentos em inteligência artificial. Além disso ainda criou uma máquina que resolvia o cubo mágico, uma máquina de malabarismo e até mesmo uma máquina para ler a mente. Shannon dizia que era motivado pela curiosidade ao invés da utilidade de suas invenções. Ele mesmo dizia: "Eu só queria saber como as coisas funcionavam."

Em 1948, Claude Shannon escreveu seu artigo mais importante, que veio a ser um marco, "A Mathematical Theory of Communication". Ele começou esse paper pioneiro em teoria da informação observando que: "O problema fundamental da comunicação é o de reproduzir em um ponto exatamente ou aproximadamente uma mensagem selecionada em outro ponto" (11). Ele então continua estabelecendo de forma tão completa os fundamentos da teoria da informação, que até hoje seu arcabouço e sua terminologia permanecem como sendo o padrão.

Essa teoria foi um sucesso imediato entre os engenheiros de comunicação e estimulou a tecnologia que levou ao que chamamos hoje de Era da Informação. Todas as linhas de comunicação hoje são medidas em bits por segundo, uma noção que Shannon usou para definir a capacidade de um canal de comunicação. Sua teoria foi o que fez possível o uso de bits em computadores para armazenamento necessário por figuras, sons e outros dados.

Um outro trabalho famoso de Shannon foi um paper de 1949 chamado: "Communication Theory of Secrecy Systems". Este trabalho é normalmente lembrado como o que fez a criptografia ser encarada não mais como arte mas sim como ciência.

Ganhou muitos prêmios e concessões, dentre eles: Concessão Morris Liebmann Memorial do Instituto de Engenheiros de Radio (1949), A Medalha Stuart Ballantine do Instituto Franklin (1955), Concessão Corporação de Pesquisa (1956), Medalha de Honra da Universidade Rice (1962), Concessão Marvin J. Kelly (1962), Medalha de Honra da I.E.E.E. (1966), Medalha Nacional de Ciências(1966) entregue pelo Presidente Johnson, Prêmio Golden Plate(1967), Prêmio Harvey, Technion, Haifa (1972) entregue pelo Presidente de Israel, Concessão Jacquard (1978), Prêmio Harold Pender (1978), Medalha de Ouro da Sociedade de Engenharia de Audio (1985), O Prêmio de Kyoto (1985) e o Prêmio Eduard Rhein (1991).

Além dos diversos prêmios, o Professor Shannon, recebeu ainda diversos títulos honorários: Yale (Mestre em Ciências, 1954), Michigan (1961), Princeton (1962), Edinburgh (1964), Pittsburgh (1964), Northwestern (1970), Oxford (1978), East Anglia (1982), 
Carnegie-Mellon (1984), Tufts (1987) e da Universidade da Pennsylvania (1991).

Durante o tempo em que trabalho no Bell Labs, conheceu sua esposa Mary Elizabeth "Betty" Moore, uma analista, com quem se casou em 1949. Teve 2 filhos, Andrew e Margarita.

Claude Shannon morreu no dia 24 de Fevereiro de 2001, aos 84 anos, depois de uma longa luta contra o mal de Alzheimer.

Para mais detalhes (28), (29), (30) e (31) 


\section{Referências}

1 LATHI, B. P. Modern Digital and Analog Communication Systems. [S.1.]: Oxford University Press, 1998.

2 BARRERA, J. et al. An environment for knowledge discovery in biology. Computers in Biology and Medicine, p. 427-447, 2004.

3 GRAY, R. M. Entropy and Information Theory. New York, New York: SpringerVerlag, 1990.

4 BASU, D. Statistical information and likelihood. Sankhyâa, 1975.

5 SCOTT, D. W. On optimal and data-based histograms. Biometrika, v. 66, p. 605-610, 1979.

6 BUSSAB, W. O.; MORETTIN, P. A. Estatística Básica. [S.1.]: Atual Editora, 1987.

7 CORMEN, T. H. et al. Introduction to Algorithms. [S.l.]: McGraw-Hill Higher Education, 2001. ISBN 0070131511.

8 SHAPIRO, G. P.; FRAWLEY, W. Knowledge Discovery in Databases. Cambridge, MA, USA: MIT Press, 1991. ISBN 0262660709.

9 SETZER, V. W. Dado, informação, conhecimento e competência. Datagrama Zero, 1997.

10 DEGROOT, M. H. Uncertaintly, information, and sequential experiments. Carnegie Institute of Technology, 1961.

11 SHANNON, C. A mathematical theory of communication. Bell Syst. Tech. J., p. 379-423, 623-656, 1948.

12 PRANG, T. Unsupervised Data Mining in Nominally-Supported Databases. [S.1.], 1998.

13 FEINSTEIN, F. Foundations of Information Theory. [S.l.]: McGraw Hill, New York, 1958.

14 ACZéL, J.; DARóCZY, Z. On Measures of Information and Their Generalizations. [S.l.]: Academic Press, New York, 1975.

15 MATHAI, A.; RATHIE, P. Basic Concepts in Information Theory and Statistics. [S.l.]: Wiley Eastern Ltd., New Delhi., 1975. 
16 PEREIRA, C. A. d. B.; STERN, J. M. Inferência Indutiva: Uma Visão Genuinamente Bayesiana. [S.l.: s.n.], 2005. Versão Preliminar, Rel: 0.2004.01.05.

17 DOUGHERTY, J.; KOHAVI, R.; SAHAMI, M. Supervised and unsupervised discretization of continuous features. In: ICML. [S.l.: s.n.], 1995. p. 194-202.

18 KOHAVI, R.; SAHAMI, M. Error-based and entropy-based discretization of continuous features. In: KDD. [S.l.: s.n.], 1996. p. 114-119.

19 FAYYAD, U. M.; IRANI, K. B. Multi-interval discretization of continuous-valued attributes for classification learning. In: IJCAI. [S.l.: s.n.], 1993. p. 1022-1029.

20 GRÜNWALD, P. et al. Minimum encoding approaches for predictive modeling. In: UAI. [S.l.: s.n.], 1998. p. 183-192.

21 AL., P. C. et. Discovering data mining: from concept to implementation. [S.1.]: Prentice Hall, Inc, 1997. 9 p.

22 ELMASRI, S. B. N. R. Fundamentals of Database Systems. 3. ed. [S.1.]: Addison-Wesley, 2000.

23 WITTEN, I. H.; FRANK, E. Data mining: practical machine learning tools and techniques with Java implementations. San Francisco, CA, USA: Morgan Kaufmann Publishers Inc., 2000. ISBN 1-55860-552-5.

24 GRISWOLD, D. The Java HotSpot Virtual Machine Architecture. 1998. Disponível em: <http://java.sun.com/ products/hotspot/whitepaper.html>. Acesso em: 29 jun. 2005.

25 INTERNATIONAL, I. O. T. Eclipse platform technical overview. 2003. Disponível em: <http://www.eclipse.org/whitepapers/eclipse-overview.pdf>. Acesso em: 29 jun. 2005.

26 HETTICH, C. B. S.; MERZ, C. UCI Repository of machine learning databases. 1998. Disponível em: <http://www.ics.uci.edu/ mlearn/MLRepository.html>. Acesso em: 29 jun. 2005.

27 YANG, Y.; WEBB, G. Discretization for naive-bayes learning: managing discretization bias and variance. 2003. Disponível em: <citeseer.ist.psu.edu/yang03discretization.html>. Acesso em: 29 jun. 2005.

28 MIT. MIT Professor Claude Shannon dies; was founder of digital communications. 2001. Disponível em: <http://web.mit.edu/newsoffice/2001/shannon.html>. Acesso em: 29 jun. 2005.

29 LABS, B. Claude Shannon, Father of Information Theory, Dies at 84. 2001. Disponivel em: <http://www.bell-labs.com/news/2001/february/26/1.html>. Acesso em: 29 jun. 2005.

30 SLOAne, N.; WYNer, A. Claude Shannon: Collected Papers. 445 Hoes Lane, PO Box 1331, Piscataway NJ 08855, USA: IEEE Press, 1993. 
31 WYNER, A. D. The significance of Shannon's Work. 1997. Disponível em: $<$ http://cm.bell-labs.com/cm/ms/what/shannonday/work.html >. Acesso em: 29 jun. 2005. 